\title{
BONE CHEMISTRY AT CERRO OREJA: A STABLE ISOTOPE PERSPECTIVE ON THE DEVELOPMENT OF A REGIONAL ECONOMY IN THE MOCHE VALLEY, PERU DURING THE EARLY INTERMEDIATE PERIOD
}

\author{
Patricia M. Lambert, Celeste Marie Gagnon, Brian R. Billman, M. Anne Katzenberg, \\ José Carcelén, and Robert H. Tykot
}

\begin{abstract}
In this paper we test the hypothesis that an intensification of maize production preceded the development of a regional Moche political economy in the Moche Valley of north coastal Peru during the Early Intermediate period (400 B.C.-A.D. 600). To do so we analyze stable isotopic signatures of 48 bone apatite and 17 tooth enamel samples from human remains recovered from the site of Cerro Oreja, a large urban and ceremonial center in the Moche Valley. These remains date to the Guañape, Salinar, or Gallinazo phases and provide a diachronic picture of subsistence before the appearance of the Southern Moche state. The most notable patterns identified in the study include a lack of significant change in $\delta^{13} C_{\text {apatite }}$ values from the Guañape to Salinar phases, followed by a significant enrichment in $\delta^{13} C_{\text {apatite }}$ values from the Salinar to Gallinazo phases. Several lines of evidence, including archaeological context, dental data, and comparative carbon stable isotope data from experimental animal studies and studies of archaeological human remains support the interpretation that the observed ${ }^{13} \mathrm{C}$ enrichment in stable isotope values in the Gallinazo phase primarily reflects maize intensification. The stable isotope data from Cerro Oreja thus suggest that a shift in subsistence toward a highly productive and storable crop may have served as an important precursor to state development during the Early Intermediate period in the Moche Valley.
\end{abstract}

En este trabajo se prueba la hipótesis de que una intensificación de la producción de maíz precedió al desarrollo de una economía política regional moche en el Valle de Moche de la costa norte del Perú durante el período Intermedio Temprano (400 a.C.-600 d.C.). Para ello se analizan firmas isotópicas estables de 48 muestras de apatita de huesos y 17 muestras de esmalte dental de los restos humanos recuperados en el sitio de Cerro Oreja, un gran centro urbano y ceremonial en el Valle de Moche. Estos restos datan de las épocas Guañape, Salinar o Gallinazo y proporcionan una visión diacrónica de la subsistencia anterior a la aparición del estado moche del sur. Los patrones más notables identificados en el estudio incluyen la falta de cambios significativos en los valores de la $\delta^{13} C_{\text {apatita }}$ entre las épocas Guañape y Salinar, seguida por un importante enriquecimiento de los valores de $\delta^{13} C_{\text {apatita }}$ entre las épocas Salinar y Gallinazo. Este enriquecimiento podría haber ocurrido de tres maneras: 1) los ocupantes de la época Gallinazo Cerro Oreja podrían haber aumentado su producción de maíz; 2) estos mismos podrían haber intensificado el uso de los recursos marinos; o 3) que ellos podrían haber intensificado el uso y la producción de maíz y los recursos marinos, respectivamente. Varias líneas de evidencia apoyan la primera hipótesis, incluyendo el contexto arqueológico, los datos dentales y los datos comparativos de isótopos de carbono de los estudios experimentales con animales y la investigación de restos humanos arqueológicos que une los valores $\delta^{13} C_{\text {apatita }}$ similares a los observados en la muestra de la época Gallinazo con una dieta a base de maíz. Los datos de isótopos estables de Cerro Oreja por lo tanto sugieren que un cambio en la subsistencia hacia un cultivo altamente productivo y almacenable puede haber servido como un importante precursor para el desarrollo del estado durante el período Intermedio Temprano en el Valle de Moche.

$\mathrm{I}$

$\mathrm{n}$ this paper we examine the role that changes in agricultural production played in the development of a regional political economy in the Early Intermediate period (EIP; 400 B.C.-A.D.

600 ) in the Moche Valley of north coastal Peru. The north coast is one of several Andean regions where centralized political organizations formed in the precolumbian era. No political system on the north

Patricia M. Lambert a Anthropology Program, Utah State University, Logan, UT 84321 (patricia.lambert@usu.edu)

Celeste Marie Gagnon a Department of Anthropology, Wagner College, Staten Island, NY 10301

Brian R. Billman — Department of Anthropology, University of North Carolina at Chapel Hill, Chapel Hill, NC 27599

M. Anne Katzenberg - Department of Archaeology, University of Calgary, Calgary, Alberta, Canada T2N 1N4

José Carcelén - Instituto Nacional de Cultura-La Libertad, Trujillo, Peru

Robert H. Tykot $\mathbf{\square}$ Department of Anthropology, University of South Florida, Tampa, FL 33620

Latin American Antiquity 23(2), 2012, pp. 144-166

Copyright (C2012 by the Society for American Archaeology 
coast has received more attention or been the subject of greater debate than the various Moche polities (A.D. 300-800). Although diverse in form and historical development, Moche polities were characterized by the construction of massive ceremonial centers, intricate iconographic representations of an elite religious ideology, lavish elite burials, craft specialization, and social stratification (see Bawden 1995, 1996; Billman 2010; Pillsbury 2001; Quilter and Castillo 2010).

Not surprisingly, questions related to the origins and structure of Moche political organizations, ritual practices, and elite ideology have engaged archaeologists working in this region since the work of Rafael Larco in the mid-twentieth century (Castillo 2010). Several prominent theories have been proposed to explain political change in this and other regions of Peru, including those invoking Wittfogel's $(1956,1971)$ hydraulic hypothesis (e.g., Haas 1987; Moseley 1974; Stanish 1994), warfare (e.g., Billman 1996; Wilson 1981, 1988), and changes in agricultural production (e.g., Billman 2002, 2010; Burger and van der Merwe 1990; Hastorf and Johannessen 1993; Kellner and Schoeninger 2008; Quilter and Stocker 1983). Those invoking agricultural change have focused on shifts in maize production, because this grain can produce high yields in certain environments; it is easily stored for long periods; and it is known to have had a prominent role in prehistoric Andean social, political, and ceremonial life (e.g., Hastorf and Johannessen 1993; Johannessen and Hastorf 1995; Kellner and Schoeninger 2008). The purpose of this study is to test the hypothesis that maize intensification played a role in the origins of a regional Moche polity in the Moche Valley, commonly referred to as the Southern Moche state. ${ }^{1}$

In the 1990s, Billman set out to test Wittfogel's hydraulic hypothesis of state origins in the Moche Valley, using extensive survey data from the lower and middle valleys to chart the expansion of canal systems and the rise and fall of polities from 1800 B.C. through A.D. 600 (Billman 1996, 2002). The study examined changes in the organizational requirements of the construction and maintenance of irrigation from the start of small-scale irrigation in the middle valley circa 1800 B.C. to the construction of large-scale irrigation projects on the north side of the lower valley in the Middle Moche phase. Results of the study indicated that the man- agerial requirements of irrigation were relatively unimportant; rather, warfare, highland-coastal interaction, and political control of irrigation systems created opportunities for leaders to form a highly centralized polity beginning around A.D. 300 (Billman 2002).

This new polity (the Southern Moche state) was profoundly different from antecedent polities in that Moche rulers exercised significant economic, military, and ideological power over the population of the Moche Valley and beyond (Billman 2010). Moche leaders based at the Huacas de Moche were able to mobilize large quantities of labor on a regular basis to construct massive monuments and irrigation canals, and to fund craft production and elaborate public rituals. The extent of labor mobilization is demonstrated by the construction of Huaca de la Luna and Huaca del Sol, which required the production of 180 million adobes over the course of perhaps 200 or 300 years (Hastings and Moseley 1975).

Billman (2010) proposed that this regional political economy was based primarily on the extraction of tribute from farming households in exchange for access to land and water. Collection of tribute in the form of staples would have required fundamental changes in the domestic economy of farmers. In addition to expansion of irrigation, farmers would have had to make changes in the types and proportions of cultigens grown, reduce crop fallowing time, and increase yields through the use of manure or guano in order to accommodate the demands of the regional political economy. In turn, these economic shifts would have resulted in changing patterns of labor, gender roles, and diet (Gagnon 2006:265-266; Gagnon and Wiesen 2011)

What role did maize play in this transformation of agricultural production? Maize played a key role in the political economy of a wide range of Andean polities, most notably the Inka empire (Bray 2009). Maize agriculture was (and still is) highly productive in coastal valleys, and the grain is readily storable and can be transported efficiently over short to intermediate distances by llamas. Further, the provisioning of fiestas, religious festivals, and work parties with chicha de maíz (corn beer) was considered an obligation of the Inka and Chimu empires, and by inference other earlier polities (Gagnon 2006:253; Hastorf and Johannessen 1993; Hayashida 2009; Moore 1989; Ramirez 1996; Ube- 


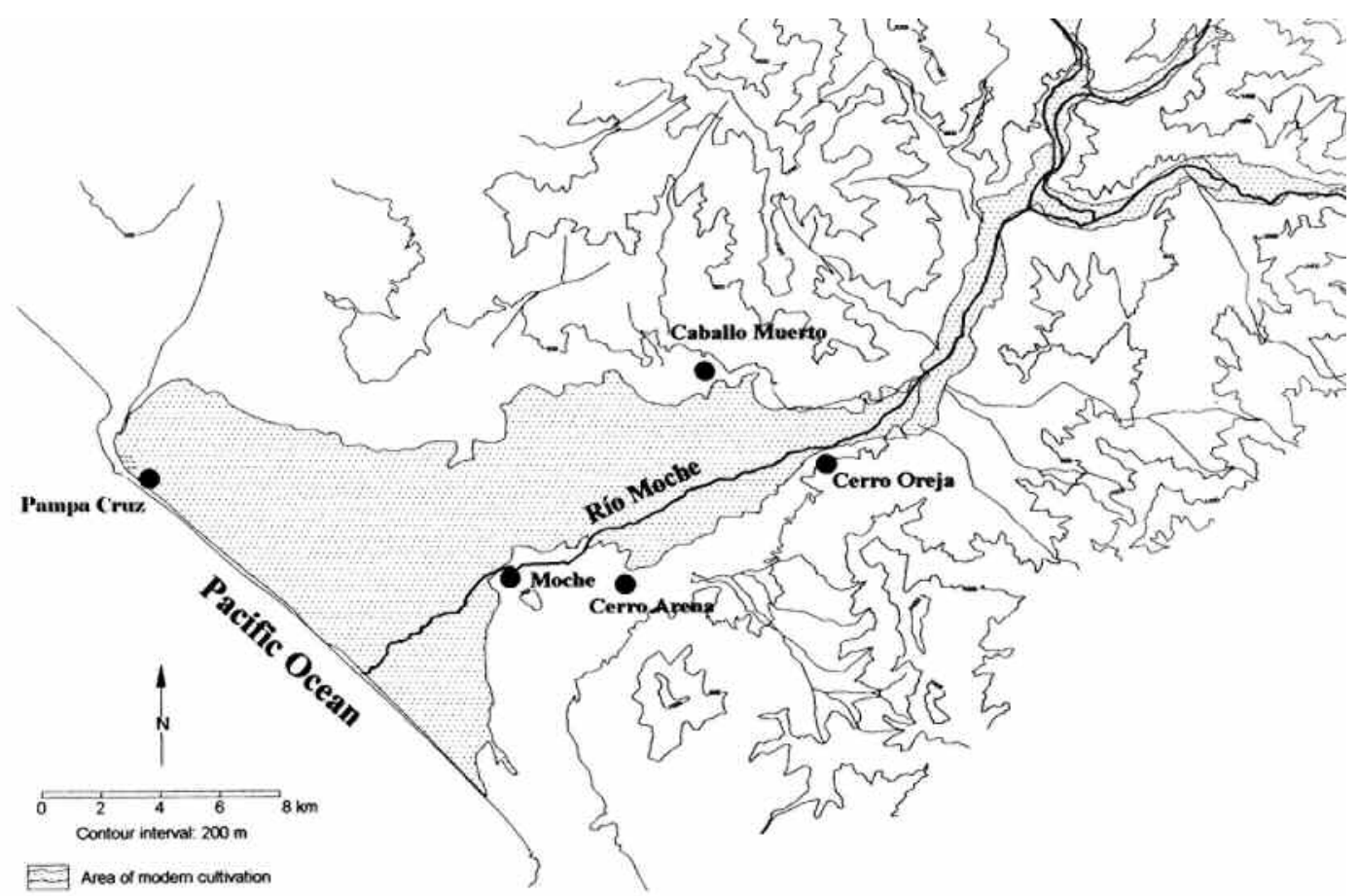

Figure 1. Map of Moche valley archaeological sites discussed in the text.

laker et al. 1995). Consequently, a shift to the intensive production of maize may have played an important role in the emergence of a regional Moche political economy based in the Moche Valley. Such a shift in maize production also might have led to changes in diet as farmers produced more maize in their fields and consumed more chicha at fiestas, religious gatherings, and work projects sponsored by rulers.

Dental health data from individuals buried at the site of Cerro Oreja (VM-710:510), a large urban and ceremonial center in the Moche Valley, provide evidence that a shift toward an increasingly cariogenic diet, such as maize would provide, occurred during the EIP (Gagnon 2006; Gagnon and Wiesen 2011). Dental caries, dental abscesses, and antemortem tooth loss have long been used as proxy measures of dietary change due to the welldocumented relationship between dental disease and the consumption of refined carbohydrates (e.g., Cohen and Armelagos 1984; Hillson 1996; Kelley and Larsen 1991; Lambert 2000; Larsen 1997; Lukacs 1989; Turner 1979). At Cerro Oreja, a significant increase in the frequency of these dental indicators suggests that such a dietary shift occurred between the Salinar and Gallinazo phases (Gagnon 2006:155-166).

In this article we investigate this apparent dietary shift through the analysis of stable isotopes in human skeletal remains recovered from Cerro Oreja. The Cerro Oreja remains date to three sequential phases preceding the first construction episodes of Huaca de la Luna and Huaca del Sol in the A.D. 300s. The stable isotope data provide us with direct evidence of diet and thus can be used to examine possible shifts in political economy that pre-date the Southern Moche state.

\section{Background}

\section{Prehistory of the Moche Valley}

The primary focus of this article is the Salinar, Gallinazo, and Early Moche phases of the EIP in the Moche Valley (Figure 1). A few Guañape phase burials from the Initial period and Early horizon (1800-400 B.C.) are also included in the study and provide a glimpse into subsistence in this earlier period. The time frame represented by the human skeletal sample encompasses the period during 
which irrigation agriculture became established in the valley (Billman 1996, 2002).

During the Late Preceramic period (2700-1800 B.C.) a mixed economy based on marine resources and small-scale farming was established in the Moche Valley (Pozorski 1979, 1983). Marine resources exploited included mollusks, near-shore fish, and marine birds. Cultigens included gourds, cotton, squash, beans, peppers, peanuts, and several fruits, which were probably grown in small plots in sunken fields and on the floodplain of the river.

By 1800 B.C. at the start of the Guañape phase, most of the population moved from coastal settlements to the middle Moche Valley in the foothills of the Andes. People constructed small irrigation canals and presumably focused subsistence activities on agriculture rather than fishing. By the end of the Guañape phase over 4,000 ha of land was under irrigation (Billman 1996, 2002:380). In the Early Guañape phase (1800-1300 B.C.), the first mounds were constructed in the valley. Mound construction peaked in the Middle Guañape phase (1300-800 B.C.) with the construction of mounds at Caballo Muerto and several intermediate and small mounds at other sites (Billman 1996, 2002; Chauchat et al. 2006; Pozorski and Pozorski 1979; T. Pozorski 1982). Mound construction totaled more than $400,000 \mathrm{~m}^{2}$ (Billman 1996:185, 2002). Cerro Oreja, the focus of this study, contains both Guañape phase burials and unexcavated habitations (Billman 1996) and is located across the river from Caballo Muerto and adjacent to Huaca Huatape, an intermediate-sized Guañape phase mound. The use and construction of mounds continued into the Late Guañape phase (800-400 B.C.).

At the start of the EIP in the Salinar phase (400-1 B.C.), the political landscape of the Moche Valley changed dramatically (Billman 1999). All the Guañape phase ceremonial centers, including the paramount site of Caballo Muerto, were abandoned, settlement of the lower valley expanded dramatically, the first formal fortifications were constructed and the valley's population aggregated into eight discrete site clusters (Billman 1996, 1999). Cerro Oreja was one of the few Guañape phase sites that continued to be occupied. During the Salinar phase the population of Cerro Oreja expanded, making it the second largest settlement in the valley; Cerro Arena was the largest during this time period. The eight site clusters likely were autonomous polities, although Cerro Arena was probably the dominant political power in the valley as a result of its demographic advantage over the other, smaller site clusters (Billman 1996, 1999; Brennan 1978, 1980a, 1980b; Mujica 1975). The political fragmentation of the valley, the abandonment of Guañape phase centers, and the shifts in population were probably the result of the onset of armed conflict between the coastal and highland groups, and among polities of various coastal valleys (Billman 1996, 1999, 2002). Irrigation in the Moche Valley expanded, increasing productive land to between 6,750 and 7,300 ha, a 73 percent increase over the preceding period (Billman 1996, 2002:382; Moseley and Deeds 1982). Although detailed data on food refuse are lacking for the Salinar phase, the expansion of irrigation suggests a transition from a mixed economic system anchored on the exploitation of marine protein and smallscale farming to a system of intensive agriculture (Billman 1996; Gagnon 2006:25).

In the Gallinazo phase (A.D. 1-200) the Moche Valley was unified under a single polity centered at Cerro Oreja (Billman 1996, 1999). Cerro Arena, which had a population between 5,000 and 10,000, was abandoned and the population of Cerro Oreja increased dramatically, making it the largest settlement in the valley. At its peak, perhaps more than 7,000 people lived at the site. Densely packed residences extended for $2 \mathrm{~km}$ along the lower slopes of Cerro Oreja. Up valley from Cerro Oreja, the population was concentrated at a series of fortified hilltop towns, which were linked visually. On the coast at Huanchaco, Pampa Cruz grew into a large fishing community, second in population only to Cerro Oreja (Billman 1996:239-242).

Leaders of the Cerro Oreja polity apparently controlled more labor than the smaller Salinar phase polities of the Moche Valley. Investment in public architecture grew from $15,000 \mathrm{~m}^{3}$ in the Salinar phase to over $60,000 \mathrm{~m}^{3}$ in the Gallinazo phase (Billman 2002:390). At Cerro Oreja, a large adobe mound measuring 110 by 35 by $8.5 \mathrm{~m}$ clings to the steep slopes above the residential area of the site. In order to create a level area to construct the mound, a cut-and-fill terrace, measuring 35 by $110 \mathrm{~m}$, was carved out of the slopes. The masonry retaining walls for this terrace were massive, standing over $6 \mathrm{~m}$ tall (Billman 1996:241; Brisceño et al. 2006). 
This new construction project demonstrates that leaders at Cerro Oreja could mobilize large groups for extended periods for construction projects.

The concentration of the population and political power at Cerro Oreja meant the Cerro Oreja polity was well-positioned to control large tracts of highly productive, irrigated land. Due to the topography of the Moche Valley, the canal intakes that water most of the broad alluvial fan of the lower valley originate at or just above Cerro Oreja. If one controls these intakes, one controls over 80 percent of the cultivable land in the lower valley. While the irrigation system did not expand significantly (Billman 2002:383), the choice of Cerro Oreja as the Gallinazo phase center is strong evidence that control of agricultural resources was essential to the power structure of the Cerro Oreja polity. The lack of major canal expansion may indicate that agricultural production stabilized during this phase, but it is equally plausible that food production was intensified through shifts in crops produced (Gagnon 2006; Gagnon and Wiesen 2011), the use of guano or manure, decreases in the length of fallowing, and the development of new and more productive varieties of cultigens, especially maize (see Bird and Bird 1980).

By the end of the Early Moche phase (A.D. 200-300), a new political and ceremonial center was founded at Huacas de Moche (Bawden 1996; Billman 1996, 2010; Moseley 1975; Topic 1977, 1982; Uceda 2001; Uceda et al. 1994). Cerro Oreja continued to be occupied, although the population may have declined. At Huacas de Moche the construction of Huaca de la Luna and Huaca del Sol was started (Uceda 2001; Uceda et al. 1994). The latter monument eventually became the largest adobe structure ever constructed in the New World (Hastings and Moseley 1975). These new monuments were radically different in form and function from antecedent monuments of the Salinar and Gallinazo phases (Billman 1996,2010). New forms of public rituals that involved human sacrifice and the burial of select individuals with unprecedented quantities of grave goods were performed at the monuments (Billman 2010; Bourget 1996, 2001; Uceda 2001; Verano 2000, 2001). Adjacent to Huaca de la Luna, craft specialists turned out vast quantities of ceramic goods for use in domestic and mortuary rituals (Bernier 2010; Uceda and Armas 1997, 1998). Beyond the Huacas de Moche, a major expansion and reorganization of settlement occurred in the valley with the construction of large numbers of new settlements and monumental centers. Three massive canals were constructed on the north side of the Moche Valley, opening several thousand hectares of irrigated land (Billman 1996, 2002, 2010; Moseley and Deeds 1982).

Collectively these transformations indicate a profound change in the relationships between rulers and the people of the valley (Billman 2010). Moche rulers were able to harness labor and collect large quantities of goods on a regular basis from commoner households, which they used to finance a broad range of political activities, including monumental construction, public rituals, craft production, land reclamation, and possibly military actions. These transformations were manifestations of the emergence of a new regional political economy in which Moche rulers exercised significant economic, military, and ideological power over the population of the Moche and adjacent valleys.

While the Moche phase is not the primary focus of this research, the origins of the Moche polity at Huacas de Moche is. The Huacas de Moche polity (aka the Southern Moche state) was the culmination of earlier political and economic developments in the Moche and adjacent valleys, though none of the preceding polities on the North Coast achieved its size or level of complexity. The dramatic expansion of the political economy in the Middle Moche phase required the mobilization of unprecedented quantities of food stuffs to support public works projects, craft specialists, elite families, and massive public gatherings at Huaca de la Luna. These activities could not have been undertaken without an equally dramatic intensification of agricultural production.

This paper examines whether or not shifts in diet related to the intensification of agricultural production in the Moche Valley occurred before the dramatic expansion of the political economy in the Middle Moche phase, or only after and in consequence of the rise of the Moche polity. To examine this question we test the following hypotheses:

\section{$\mathrm{H}_{0}$ There was no significant change in the sub- sistence regime in the Gallinazo phase.}

$\mathrm{H}_{\mathrm{A}}$ An intensification of maize production in the Gallinazo phase preceded the development of a regional Moche polity in the Moche Valley. 
These hypotheses are evaluated through the analysis of stable isotopes in human bones and teeth from the Cerro Oreja cemetery.

\section{Stable Isotopes}

Stable isotope analysis is a well-established tool for reconstructing diet in archaeological contexts (e.g., Katzenberg 1989; Kellner and Schoeninger 2008; Larsen et al. 1992; Tykot 2006; Vogel and van der Merwe 1977; Walker and DeNiro 1986). Stable carbon isotopes from preserved bone collagen were first used in paleodiet studies to indicate the presence of $\mathrm{C}_{4}$ plants such as maize in the diet of people living in temperate regions (van der Merwe and Vogel 1978; Vogel and van der Merwe 1977). In North America, where the adoption and intensification of maize agriculture is the most significant economic transition to occur in most regions prehistorically, stable carbon isotope analysis has been used extensively to examine the timing and tempo of this transition (e.g., Buikstra and Milner 1991; Katzenberg et al. 1995; Schurr and Redmond 1991; van der Merwe and Vogel 1978; Vogel and van der Merwe 1977). Stable isotopes of nitrogen are often used in conjunction with stable carbon isotopes to provide information on trophic level, as well as the use of marine foods and certain plant food groups in the diet (e.g., Katzenberg 1989; Price et al.1985; Sealy et al. 1987; Walker and DeNiro 1986). In South America, these dietary tracers have been used to detect the introduction of maize into the diet and to assess the importance of marine resources (e.g., Burger and van der Merwe 1990; Hastorf 1985; Hastorf and DeNiro 1985; Sandness 1992; Tykot and Staller 2002).

Carbon atoms from ingested foods are stored in two sites in the human skeleton: bone collagen and carbonate. Bone collagen is a protein and, while many of the amino acids in collagen are non-essential (i.e., can be synthesized within the body), controlled feeding experiments demonstrate that collagen nonetheless reflects the protein portion of the diet to a greater degree than it reflects the total diet (Ambrose and Norr 1993; Tieszen and Fagre 1993). Carbonate is a component of hydroxyapatite, the mineral portion of bone and tooth enamel. Carbonate from bone mineral is an attractive source for stable carbon isotope measurements in regions where bone preservation is poor because collagen may be too degraded to yield reliable results (Krig- baum 2003; van der Merwe et al. 1993). Krueger and Sullivan (1984) first suggested that carbonate would better reflect the whole diet, and this was supported by controlled feeding experiments such as those cited above. Subsequently a number of paleodiet studies have made use of both sources of carbon (e.g., Harrison and Katzenberg 2003; Kellner and Schoeninger 2007; Tykot and Staller 2002; Ubelaker et al. 1995).

Both collagen and bone apatite are subject to turnover as a result of bone maintenance and repair, whereas tooth enamel is not. For this reason, the isotopic signatures of bone collagen and apatite reflect dietary averages over the last 10 to $20+$ years of a person's life (Hedges et al. 2007), whereas tooth enamel provides a measure of diet during the years of enamel formation (Eerkens et al. 2011; Wright and Schwarcz 1998).

Controlled feeding studies of rats and mice (Ambrose and Norr 1993; Tieszen and Fagre 1993) indicate that collagen is enriched in the heavier isotope of carbon $\left({ }^{13} \mathrm{C}\right)$ relative to the diet by approximately $5 \%$, although this number may vary depending on the specific diet and on the size of the animal (Table 1). Experimental studies further suggest that the $\delta^{13} \mathrm{C}$ value of carbonate in the apatite of bone mineral (hereafter referred to as $\delta^{13} C_{\text {apatite }}$ ) better reflects the $\delta^{13} \mathrm{C}$ of bulk carbon in the diet, but with a greater enrichment relative to whole diet on the order of about $9 \%$ in rodent models. However, both of these numbers can vary and neither has been experimentally determined in humans. Research on archaeological remains suggests that $\delta^{13} \mathrm{C}_{\text {apatite }}$ enrichment in humans may be more on the order of $12 \%$ (Harrison and Katzenberg 2003; Tykot et al. 2009), the figure used in this study to estimate $\delta^{13} C_{\text {diet }}$ from $\delta^{13} C_{\text {apatite }}$ values. All terrestrial plants and the animals that consume them initially obtain their carbon from atmospheric $\mathrm{CO}_{2}$. Due to deforestation and the widespread burning of fossil fuels, which are depleted in the heavier isotope of carbon, the $\delta^{13} \mathrm{C}$ of atmospheric $\mathrm{CO}_{2}$ has been decreasing and is now approximately $1.5 \%$ lower than it was prior to the industrial revolution (Boutton 1991). This number must be therefore subtracted from $\delta^{13} \mathrm{C}$ values derived from prehistoric remains when making comparisons with values obtained from modern samples.

The difference between $\delta^{13} \mathrm{C}_{\text {collagen }}$ and $\delta^{13} \mathrm{C}_{\text {apatite }}$ values in a sample can provide important 
Table $1 . \delta^{13} \mathrm{C}$ Values and Diet in Experimental Animal Studies (Based on Kellner and Schoeninger 2007:1113). Sorted in Descending Order by $\delta^{13} \mathrm{C}_{\text {diet }}$ Values.

\begin{tabular}{|c|c|c|c|c|c|c|c|}
\hline$\underline{\text { Sample }}$ & $\begin{array}{c}\text { Diet: } \\
\text { aprotein/energy }\end{array}$ & $\begin{array}{c}\% \text { Marine } \\
\text { In Diet }\end{array}$ & $\begin{array}{c}\% \mathrm{C}_{4} \text { Foods } \\
\text { in Diet }\end{array}$ & $\begin{array}{l}\delta^{13} \mathrm{C} \\
\text { Diet } \\
\end{array}$ & $\begin{array}{c}\delta^{13} \mathrm{C} \\
\text { Apatite }\end{array}$ & $\begin{array}{c}\delta^{13} \mathrm{C} \\
\text { Collagen } \\
\end{array}$ & $\begin{array}{c}\Delta^{13} \mathrm{C}_{\mathrm{CA}-\mathrm{CO}} \\
\% \\
\%\end{array}$ \\
\hline \multicolumn{8}{|c|}{ Diets emphasizing $C_{3}$ foods } \\
\hline Pig-11\% Protein Diet ${ }^{\mathrm{b}}$ & $\mathrm{C}-\mathrm{C}_{3} / \mathrm{C}_{3}$ & 0 & 0 & -25.7 & -13.6 & -19.6 & 6.0 \\
\hline Mouse $^{c}$ & $\mathrm{P}-\mathrm{C}_{3} / \mathrm{C}_{3}$ & 0 & 0 & -25.6 & -16.8 & -21.9 & 5.1 \\
\hline Rat $^{\mathrm{d}}$ & $\mathrm{C}-\mathrm{C}_{3} / \mathrm{C}_{3}$ & 0 & 0 & -25.2 & -15.7 & -21.4 & 5.7 \\
\hline Rat-20\% Protein Diet ${ }^{\mathrm{e}}$ & $\mathrm{C}-\mathrm{C}_{3} / \mathrm{C}_{3}$ & 0 & 0 & -24.9 & -14.5 & -19.9 & 5.4 \\
\hline Rat-5\% Protein Diet ${ }^{\mathrm{d}}$ & $\mathrm{C}-\mathrm{C}_{4} / \mathrm{C}_{3}$ & 0 & 5.0 & -24.3 & -13.4 & -14.7 & 1.3 \\
\hline Rat-20\% Protein Diet ${ }^{\mathrm{e}}$ & $\mathrm{MF} / \mathrm{C}_{3}$ & 20.0 & 0 & -23.3 & -13.4 & -14.5 & 1.1 \\
\hline Rat- $70 \%$ Protein Diet ${ }^{\mathrm{d}}$ & $\mathrm{C}-\mathrm{C}_{3} / \mathrm{C}_{4}$ & 0 & $\sim 30.0$ & -22.5 & -13.5 & -20.7 & 7.2 \\
\hline Rat $-20 \%$ Protein Diet ${ }^{\mathrm{e}}$ & $\mathrm{C}_{4} / \mathrm{C}_{3}$ & 20.0 & 20.0 & -22.3 & -13.0 & -12.3 & .7 \\
\hline \multicolumn{8}{|c|}{ Diets emphasizing $C_{4}$ foods and mixed $C_{3} / C_{4}$ energy foods with marine protein } \\
\hline Pig-13\% Protein Diet ${ }^{\mathrm{b}}$ & $\mathrm{C}-\mathrm{C}_{3} / \mathrm{C}_{3} \& \mathrm{C}_{4}$ & 0 & 30.4 & -20.5 & -11.8 & -18.7 & 6.9 \\
\hline Rat-20\% Protein Diet ${ }^{\mathrm{e}}$ & $\mathrm{MF} / \mathrm{C}_{3} \& \mathrm{C}_{4}$ & 20.0 & 35.4 & -18.3 & -8.6 & -12.2 & 4.6 \\
\hline Pig-14\% Protein Diet ${ }^{\mathrm{b}}$ & $\mathrm{C}-\mathrm{C}_{3} / \mathrm{C}_{3} \& \mathrm{C}_{4}$ & 0 & 50.0 & -18.0 & -9.0 & -16.9 & 7.9 \\
\hline Rat $-70 \%$ Protein Diet ${ }^{\mathrm{d}}$ & $\mathrm{C}-\mathrm{C}_{4} / \mathrm{C}_{3}$ & 0 & 70.0 & -17.1 & -7.7 & -9.7 & 2.0 \\
\hline Pig-15\% Protein Diet ${ }^{\mathrm{b}}$ & $\mathrm{C}_{3} / \mathrm{C}_{3} \& \mathrm{C}_{4}$ & 0 & 69.2 & -15.9 & -6.3 & -15.4 & 9.1 \\
\hline Pig-23\% Protein Diet ${ }^{b}$ & $\mathrm{MF} / \mathrm{C}_{4}$ & 23.0 & 74.1 & -15.5 & -4.3 & -11.5 & 7.2 \\
\hline Rat-20\% Protein Diet ${ }^{\mathrm{e}}$ & $\mathrm{MF} / \mathrm{C}_{4}$ & 20.0 & 70.7 & -12.9 & -3.5 & -9.7 & 6.2 \\
\hline Rat- $20 \%$ Protein Diet ${ }^{\mathrm{e}}$ & C- $-\mathrm{C}_{4} / \mathrm{C}_{4}$ & 0 & 90.7 & -12.2 & -3.1 & -7.9 & 4.8 \\
\hline Rat-5\% Protein Diet ${ }^{\mathrm{d}}$ & $\mathrm{C}-\mathrm{C}_{3} / \mathrm{C}_{4}$ & 0 & $\sim 95.0$ & -12.1 & -2.9 & -13.7 & 11.8 \\
\hline Mouse $^{c}$ & $\mathrm{P}-\mathrm{C}_{4} / \mathrm{C}_{4}$ & 0 & 100.0 & -11.8 & -3.1 & -9.8 & 6.7 \\
\hline
\end{tabular}

aprotein source: $\mathrm{C}=$ casein, $\mathrm{P}=$ plant, $\mathrm{MF}=$ marine fish.

bHowland et al. 2003.

cTieszen and Fagre 1993.

${ }^{\mathrm{d}}$ Ambrose and Norr 1993.

e Jim et al. 2004.

insights into sources of protein and other macronutrients (e.g., carbohydrates) in the diet, particularly when these vary in $\delta^{13} \mathrm{C}$ values (Katzenberg et al. 2009; Kellner and Schoeninger 2007; Knudson et al. 2007; Tomczak 2003). While $\delta^{13} C_{\text {apatite }}$ values are always higher than $\delta^{13} \mathrm{C}_{\text {collagen }}$ values, the spacing between them $\left(\Delta^{13} \mathrm{C}_{\mathrm{CA}-\mathrm{CO}}\right)$ is variable (Ambrose and Norr 1993; Harrison and Katzenberg 2003; Kellner and Schoeninger 2007:1113), depending on and thus indicative of the various macronutrients in the diet.

In the absence of $\delta^{13} \mathrm{C}$ and $\delta^{15} \mathrm{~N}$ values from collagen, $\delta^{13} \mathrm{C}_{\text {apatite }}$ values alone can be challenging to interpret in maritime environments. This is because $\delta^{13} C_{\text {apatite }}$ values for marine food consumers overlap with those of $\mathrm{C}_{4}$ food consumers and $\delta^{13} \mathrm{C}$ values do not provide a measure of trophic level that can assist in differentiating these two groups of foods (Katzenberg 1993; Kellner and Schoeninger 2007; Norr 1995). Experimental animal studies provide one mechanism for interpreting $\delta^{13} \mathrm{C}_{\text {apatite }}$ values in terms of the relative contribution of $\mathrm{C}_{3}$ foods (most plants and the animals that consume them) versus $\mathrm{C}_{4}$ foods or marine foods, or both (Ambrose and Norr 1993; Howland et al. 2003; Jim et al. 2004; Kellner and Schoeninger 2007:1113; Tieszen and Fagre 1993). Stable isotope data from archaeological human skeletal samples where dietary composition is known, or where archaeological evidence of food remains and food processing implements have been recovered (e.g., Hastorf and Johannessen 1993), can also facilitate the interpretation of carbon isotope data in these cases. All approaches are used in this study as a basis for reconstructing diet at Cerro Oreja.

\section{Stable Isotope Research in the Andean Region of South America}

In the Andean region, stable isotope analysis has been successfully employed for over 20 years in the study of paleodiet (e.g., Burger and van der Merwe 1990; DeNiro 1988; Finucane 2007; Finu- 
cane et al. 2006; Hastorf and Johannessen 1993; Kellner and Schoeninger 2008; Knudson et al. 2007; Sandness 1992; Slovak and Paytan 2011; Tomczak 2003; Tykot 2006; Tykot et al. 2008). A number of these studies have used stable isotopes to examine the role of maize in the structuring, function and/or evolution of political economies. In one of the earliest, Burger and van der Merwe (1990) used stable carbon isotopes from human bone collagen to investigate the role of maize agriculture in the origins of the Chavín civilization in the central Andean region (ca. 850 B.C.). Contrary to their expectations, they found only a slight change in maize use during the growth and efflorescence of this civilization. Maize intensification does appear to have played a role in the development of social hierarchy in the northern highlands of Ecuador, ca. A.D. 100-450 (Ubelaker et al. 1995), where high-status individuals were found to have consumed and controlled greater quantities of maize in the form of chicha de maíz. Imperial influence on food production was also identified isotopically by Hastorf and Johannessen (1993) in the Montaro Valley of the central Andes, ca. A.D. 500-1500. Their stable isotope data indicate that maize consumption increased from 40 to 60 percent of the diet after the Inka conquest, when chicha de maíz was appropriated as a state food to manage labor and build political ties. Kellner and Schoeninger (2008) tested a similar hypothesis in the Nasca region of southern Peru for the period A.D. 1-1000, but in this case found no evidence that the Wari polity intensified maize production for imperial needs.

Two studies of particular relevance to this investigation used stable carbon and nitrogen isotope ratios from bone collagen and apatite to explore diet and socioeconomic relationships within and among communities in coastal Peru (Slovak and Paytan 2011; Tomczak 2003). At Ancón on the central coast, Slovak and Paytan (2011) used this approach to clarify the nature of dietary practices during the Middle Horizon (A.D. 550-1000) and to assess how these may have changed due to Wari imperial influence. On the south coast, Tomczak (2003) explored dietary variation among Late Intermediate (A.D. 1000-1450) Chiribaya peoples of the Osmore Valley with respect to two models of resource use in order to address questions about the regional economy and political structure of the
Chiribaya culture. These studies are particularly useful for this analysis because they provide very refined stable isotope models of maize use in coastal communities of Peru and they demonstrate the power of stable isotopes to reveal dietary practices not otherwise evident in the archaeological record. These studies provide a highly nuanced comparative framework for interpreting stable isotope results from Cerro Oreja.

\section{Materials and Methods}

Cerro Oreja was first investigated through limited test excavation and surface mapping by members of the Chan Chan-Moche Valley Project (Moseley and Deeds 1982). In 1994 and 1995, José Carcelén directed salvage excavations at Cerro Oreja for the Instituto Nacional de Cultura-La Libertad in order to mitigate the effects of the construction of the Chavimochic Canal. Although much of the site was outside the area of impact, most of a large cemetery was excavated (Carcelén 1995) and represents one of the largest, unlooted burial samples in Peru. Jesús Briceño and Brian Billman (Briceño et al. 2006) followed this work with comprehensive total station mapping of all visible architecture and systematic surface of collection of two-thirds of the site.

An inventory of burials and grave offerings indicates that the 909 burials from this cemetery date from the Initial period through the Early Moche phase of the EIP (Carcelén 1995:114-146²), although the cemetery may not have been in continuous use over these years. Most $(n=816)$ of the burials date to the Gallinazo phase, but the sample also includes seven Guañape, 78 Salinar, six Early Moche and two possible Chimu burials (Table 2).

The cemetery has a complex depositional history (Carcelén 1995:18-20, 32-38). During the Guañape and Salinar phases, and early in the Gallinazo phase, the deceased were placed in subterranean graves, sometimes accompanied by ceramic grave goods. During the Gallinazo phase, the cemetery was covered by aeolian deposits. On top of this new surface a series of masonry chambers were constructed, in which people were buried. Later, these mortuary structures were filled and the cemetery was again capped. Late in the Gallinazo phase people were again buried in subterranean pits excavated into this new surface. 
Table 2. Temporal Affiliation of Burials in the Cerro Oreja Sample.

\begin{tabular}{|c|c|c|c|c|c|c|}
\hline \multirow{2}{*}{ Time Phase } & & \multirow{2}{*}{$\begin{array}{c}\text { No. } \\
\text { Burials }^{\mathrm{a}}\end{array}$} & \multicolumn{2}{|c|}{$\%$ Total Burials by } & \multicolumn{2}{|c|}{ Burials with Ceramics } \\
\hline & & & Sub-Phase & Phase & $\mathrm{n}$ & $\%$ \\
\hline Guañape & & 7 & - & .8 & 7 & 100.0 \\
\hline Salinar & & 78 & - & 8.6 & 55 & 70.5 \\
\hline \multirow{5}{*}{ Gallinazo } & Pre-Structural & 302 & 33.2 & 89.7 & 170 & 20.8 \\
\hline & Structural & 323 & 35.5 & & & \\
\hline & Recuay & 3 & .3 & & & \\
\hline & Post-Structural & 139 & 15.3 & & & \\
\hline & Gallinazo Unidentified & 49 & 5.4 & & & \\
\hline Moche & & 6 & - & .7 & 6 & 100.0 \\
\hline Chimu(?) & & 2 & - & .2 & 0 & 0 \\
\hline Total & & 909 & 89.7 & 100.0 & 238 & 26.2 \\
\hline
\end{tabular}

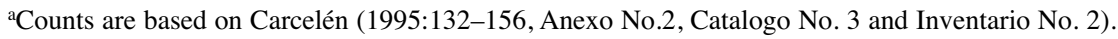

The dating of graves by Carcelén (1995:34-36) was based primarily on stratigraphy and the inclusion of ceramic vessels identified as Cupisniqiue (Guañape), Salinar, Recuay, Castillo, Gallinazo Negative, or Moche I. Using site stratigraphy Gallinazo phase interments were further divided into three sub-phases termed from earliest to most recent: Pre-Structural -interments predating the first capping of the cemetery; Structural - interments within mortuary structures; and Post-Structuralinterments postdating the second capping. In addition to the changes in grave type seen during this time, Gallinazo phase mortuary practices involving the use of ceramics at Cerro Oreja appear to have varied greatly from those that characterized earlier and later phases (Billman 2010; Donnan and Mackey 1978; Millaire 2002; Tello et al. 2003). Of the graves dating to the Guañape and Salinar phases, 100 percent and 71 percent respectively contained ceramic grave offerings (Table 2). During the Gallinazo phase this percentage fell to 21 percent. In all phases most vessels were plainware domestic forms (Carcelén 1995:132-156).

Three radiocarbon dates obtained on human bone collagen from Cerro Oreja burials help to date the Cerro Oreja cemetery sample (Table 3). The calibrated $(2 \sigma)$ range for the single Salinar sample is B.C. 418-345, although a somewhat later date of 329-205 B.C. is indicated if the diet contained a hypothetical 10 percent marine protein. The calibrated $(2 \sigma)$ ranges for two samples from the Structural Gallinazo phase are B.C. 180-A.D. 73 and B.C. 64-A.D. 93. When corrected for a hypothetical marine dietary component of 10 percent, the $2 \sigma$ range for these dates is B.C. 115-A.D. 127 and B.C. $45-$ A.D. 169 respectively. Given that the two
Gallinazo samples derive from the middle subphase of the Gallinazo phase occupation at Cerro Oreja, either estimate produces bracketing dates for the Gallinazo occupation at Cerro Oreja of about 50 B.C.-A.D. 120.

Of the total 909 burials excavated from Cerro Oreja's largest cemetery, 681 have been analyzed (Gagnon 2006). As some graves contained the remains of more than one person, the total number of individuals thus far examined is 750. Preservation of the Cerro Oreja skeletal collection ranged from good to poor, but much of it was poorly preserved-especially the Post-Structural Gallinazo stratum of burials. As a result most skeletal elements required extensive reconstruction before basic data could be collected. Teeth were similarly affected, and in many cases had to be reconstructed from tooth enamel fragments. In order to maximize the data collected, those individuals characterized as having good to fair preservation were preferentially examined (Gagnon 2006:69-70). When choosing individuals for the stable isotopic analysis, efforts were made to sample all time periods and sections of the cemetery to provide broad representation within and across temporal samples (Figure 2). Both males and females, and individuals of varying ages were included in the sample. However, as bone quality can affect stable isotopic analysis, the sampling strategy was skewed toward those individuals with the best preservation, and the final stable isotopic sample therefore does not equally represent all temporal phases.

Bone collagen and carbonate from 48 human bone samples and 17 tooth enamel samples of 51 individuals were analyzed for stable carbon and nitrogen isotopes (Table 4). In order to prevent fur- 
Table 3. Radiocarbon Dates on Human Bone from Cerro Oreja.

\begin{tabular}{|c|c|c|c|c|c|c|}
\hline $\begin{array}{l}\text { Assigned } \\
\text { Phase }\end{array}$ & Burial & $\begin{array}{c}\text { Conventional } \\
\text { RC Age }^{\mathrm{a}}\end{array}$ & $\begin{array}{c}\text { Calibrated Age SH } \\
\text { Range-2 sigma }\end{array}$ & $p$ dist & $\begin{array}{l}\text { Mixed } \\
\text { marine }\end{array}$ & Ceramic Associations \\
\hline Salinar & 839 & $\begin{array}{l}2360 \pm 40 \mathrm{BP} \\
(\text { Beta- } 152614)\end{array}$ & $\begin{array}{c}\text { B.C. } 418-345^{\mathrm{c}} \\
\text { B.C. } 322-205 \\
\text { med. prob. } \boldsymbol{B C} 382 \pm \mathbf{3 7} \\
\text { B.C. } 398-336 \\
\text { B.C. } 329-205^{3} \\
\text { med. prob. B.C. } 267 \pm \mathbf{6 2}\end{array}$ & $\begin{array}{l}.574 \\
.383 \\
.367 \\
.633 \\
\end{array}$ & $10 \%$ & $\begin{array}{l}\text { Red ware bowl, undecorated } \\
\text { Short-necked burnished red ware jar } \\
\text { with horizontally segmented upper body }\end{array}$ \\
\hline $\begin{array}{l}\text { Gallinazo } \\
\text { Structural }\end{array}$ & 125 & $\begin{array}{l}2040 \pm 40 \mathrm{BP} \\
(\text { Beta-152612) }\end{array}$ & $\begin{array}{l}\text { B.C. } 64-\text { A.D. } 93 \\
\text { med.prob.A.D. } 14 \pm 79 \\
\text { B.C. } 45-\text { A.D. } 169 \\
\text { med.prob.A.D. } 61 \pm \mathbf{1 0 7}\end{array}$ & .924 & $\begin{array}{c}0 \\
10 \%\end{array}$ & $\begin{array}{l}\text { Two bird effigy spout \& bridge bottles with } \\
\text { band of negative painted wavy lines on body } \\
\text { Stirrup \& spout bottle with globular body } \\
\text { Bird effigy double-chambered whistling bottle } \\
\text { Short-necked pitcher with globular body, } \\
\text { flared neck \& incised geometric design on collar }\end{array}$ \\
\hline $\begin{array}{l}\text { Gallinazo } \\
\text { Structural }\end{array}$ & 425 & $\begin{array}{l}2090 \pm 50 \mathrm{BP} \\
(\text { Beta-164521) }\end{array}$ & $\begin{array}{l}\text { BC } 180-\mathrm{AD} 73 \\
\text { med. prob. B.C. } 45 \pm \mathbf{1 2 7} \\
\text { B.C. } 115-\mathrm{A} . \mathrm{D} .127 \\
\text { med.prob. A.D. } 6 \pm \mathbf{1 2 1}\end{array}$ & .995 & $10 \%$ & None \\
\hline
\end{tabular}

Note: Calibrations based on southern hemisphere atmospheric curves and mixed SH atmospheric/marine curves at 10 percent marine.

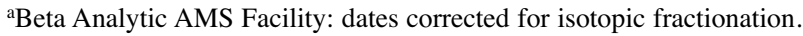

${ }^{\mathrm{b} C a l i b}$ 6.0 Radiocarbon Calibration for Southern Hemisphere. Marine Reservoir Effect for the Moche River Mouth coastal region: Delta $\mathrm{R}=165 \pm 49$ years. Median probability calculated on complete $p$ distribution (Reimer et al. 2009; Stuiver \& Reimer 2010).

${ }^{c}$ Value used in estimating mean date.

ther destruction of the collection and maintain its analytical value, isotopic samples were taken from previously fragmented ribs, long bones, and teeth; thus no complete elements were destroyed in this analysis. Due to the poor preservation of teeth and their value for many types of analyses, any that were whole or could be reconstructed were preserved and only the remaining fragments of unidentified permanent teeth were sampled for isotopic analysis. Dental enamel values in this study thus
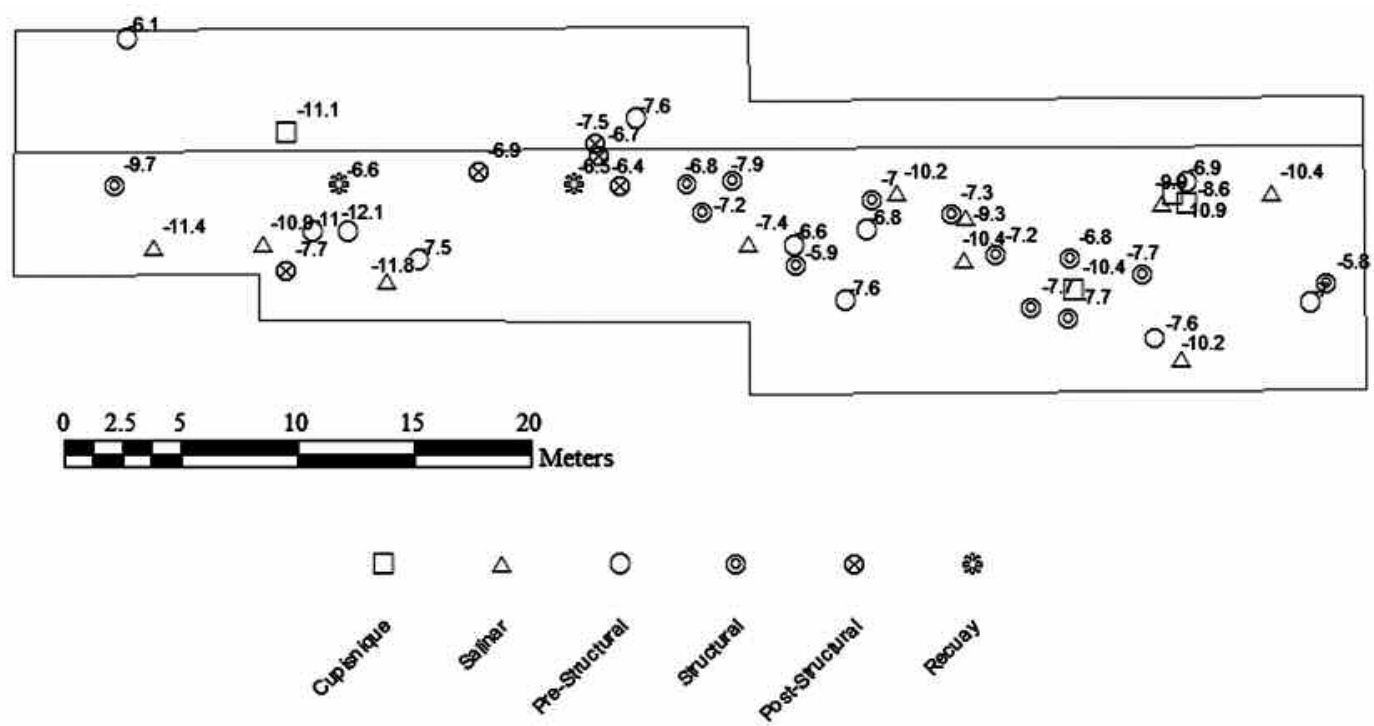

Figure 2. Distribution of burials sampled for stable isotope analysis by phase. Several individuals included in the stable isotope study were not included on field maps and are not indicated here. 
Table 4. Carbonate $\delta^{13} \mathrm{C}$ Values for Cerro Oreja Human Bones Samples by Phase.

Samples Sorted in Descending Order by $\delta^{13} \mathrm{C}_{\text {apatite }}$ Values.

\begin{tabular}{|c|c|c|c|c|c|c|}
\hline Phase & $\begin{array}{l}\text { Study } \\
\text { Phase }\end{array}$ & Burial & $\begin{array}{l}\text { Age } \\
(\text { Yrs })\end{array}$ & Sex & $\begin{array}{c}\text { Bone Apatite } \\
\delta^{13} \mathrm{C} \text { values }\end{array}$ & $\begin{array}{c}\text { Tooth Enamel } \\
\delta^{13} \mathrm{C} \text { values }\end{array}$ \\
\hline \multirow[t]{6}{*}{ Guañape } & II & 651 & $35 \pm 10$ & M & -11.1 & -11.4 \\
\hline & I & 869 & $31 \pm 5$ & $\mathrm{~F}$ & -10.9 & - \\
\hline & II & 880 & $56 \pm 10$ & $\mathrm{~F}$ & -10.4 & -11.8 \\
\hline & II & 865 & $>30$ & $\mathrm{~F}$ & -8.6 & -12.2 \\
\hline & & & & Mean Guañape $\delta^{13} \mathrm{C}$ & -10.3 & -11.8 \\
\hline & & & & Mean Guañape $\delta^{13} C_{\text {diet }}$ & -22.3 & \\
\hline \multirow[t]{12}{*}{ Salinar } & II & 660 & $33 \pm 5$ & M & - & -11.8 \\
\hline & II & 362 & $32 \pm 5$ & M & -11.4 & - \\
\hline & $\mathrm{I}$ & 739 & $19 \pm 3$ & M & -10.9 & - \\
\hline & II & 837 & $37 \pm 5$ & $\mathrm{~F}$ & -10.4 & -10.1 \\
\hline & $\mathrm{I}$ & 858 & $17 \pm 3$ & $\mathrm{~F}$ & -10.4 & - \\
\hline & II & 890 & $45 \pm 10$ & $\mathrm{~F}$ & -10.2 & - \\
\hline & II & 897 & $21 \pm 3$ & M & - & -10.2 \\
\hline & II & 861 & $30 \pm 5$ & $\mathrm{~F}$ & -9.9 & - \\
\hline & $\mathrm{I}$ & 859 & $45 \pm 10$ & M & -9.3 & \\
\hline & II & 745 & $35 \pm 8$ & $?$ & -7.4 & -6.4 \\
\hline & & & & Mean Salinar $\delta^{13} \mathrm{C}$ & -10.0 & -9.6 \\
\hline & & & & Mean Salinar $\delta^{13} C_{\text {diet }}$ & -22.0 & \\
\hline
\end{tabular}

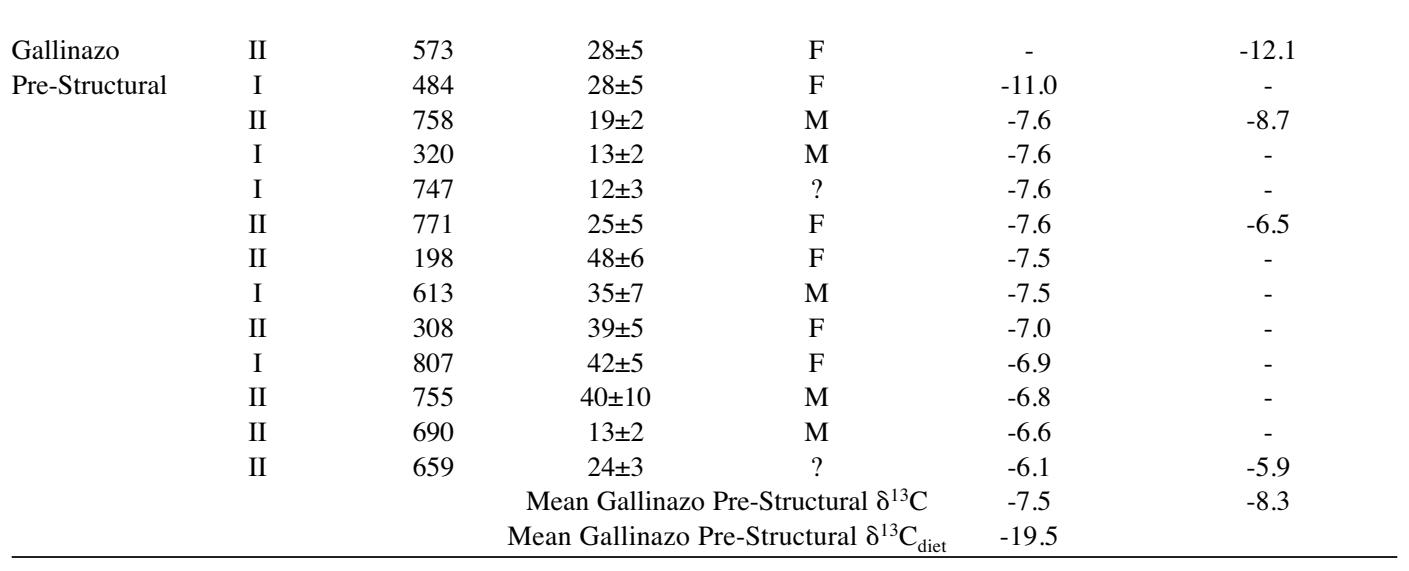

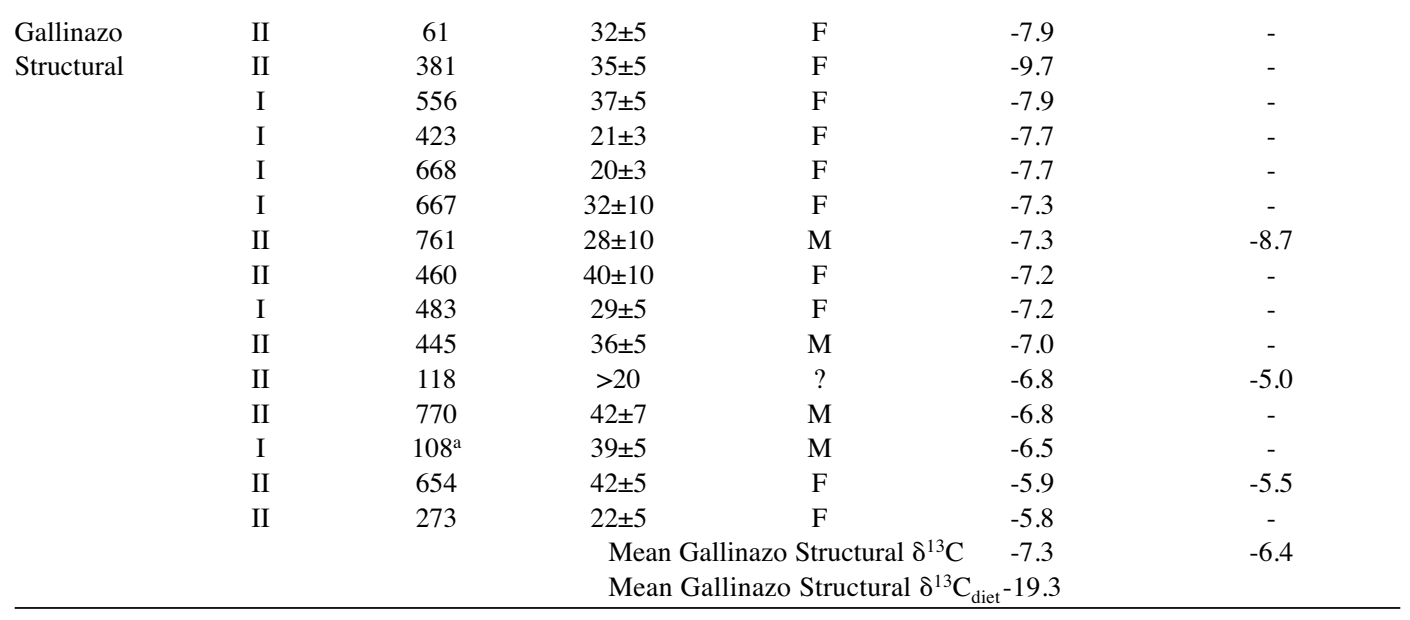


Table 4 (continued). Carbonate $\delta^{13} \mathrm{C}$ Values for Cerro Oreja Human Bones Samples by Phase. Samples Sorted in Descending Order by $\delta^{13} \mathrm{C}_{\text {apatite }}$ Values.

\begin{tabular}{|c|c|c|c|c|c|c|}
\hline Phase & $\begin{array}{l}\text { Study } \\
\text { Phase }\end{array}$ & Burial & $\begin{array}{l}\text { Age } \\
\text { (Yrs) }\end{array}$ & Sex & $\begin{array}{l}\text { Bone Apatite } \\
\delta^{13} \mathrm{C} \text { values }\end{array}$ & $\begin{array}{c}\text { Tooth Enamel } \\
\delta^{13} \mathrm{C} \text { values }\end{array}$ \\
\hline Gallinazo & II & 301 & $27 \pm 7$ & $\mathrm{~F}$ & -7.9 & - \\
\hline \multirow[t]{7}{*}{ Post-Structural } & II & 156 & $>30$ & M & -7.7 & - \\
\hline & II & 66 & $18 \pm 3$ & $\mathrm{~F}$ & -7.5 & - \\
\hline & II & $199 b$ & $46 \pm 5$ & $\mathrm{~F}$ & -6.9 & -7.8 \\
\hline & II & 65 & $27 \pm 7$ & $\mathrm{~F}$ & -6.7 & -5.3 \\
\hline & II & 60 & $27 \pm 7$ & $\mathrm{M}$ & -6.4 & -5.6 \\
\hline & \multirow{2}{*}{\multicolumn{4}{|c|}{$\begin{array}{c}\text { Mean Gallinazo Post-Structural } \delta^{13} \mathrm{C} \\
\text { Mean Gallinazo Post-Structural } \delta^{13} \mathrm{C}_{\text {diet }}\end{array}$}} & -7.2 & -6.2 \\
\hline & & & & & -19.2 & \\
\hline \multirow[t]{3}{*}{ Gallinazo-? } & I & 692 & $38 \pm 5$ & M & -11.1 & - \\
\hline & II & 907 & $35 \pm 5$ & $\mathrm{~F}$ & -7.1 & - \\
\hline & II & 144 & $18 \pm 3$ & $\mathrm{~F}$ & -6.6 & - \\
\hline
\end{tabular}

${ }^{\mathrm{a}}$ Gallinazo Recuay.

provide a general measure of diet during the period of permanent tooth crown formation: approximately six months to 12 years (White and Folkens 2005:366). The remains were analyzed in two phases. Phase I was conducted by M.Anne Katzenberg at the University of Calgary using rib samples from 16 individuals. In phase II, 32 long bone samples and 17 tooth enamel fragment samples were analyzed by Robert H. Tykot at the University of South Florida.

Methods for collagen extraction differed slightly between the two institutions. Following Sealy (1986), phase I bone was cleaned in an ultrasonic cleaner for approximately 10 minutes, then dried. Dried samples were weighed then soaked in 1 percent hydrochloric acid ( $\mathrm{HCl})$. Acid was changed several times until bone mineral was removed. The remaining organic material was soaked in $.125 \mathrm{M}$ sodium hydroxide $(\mathrm{NaOH})$ overnight. Samples were then rinsed to neutrality and centrifuged, and the remaining sample was lyopholized and weighed. In phase II, bone collagen was extracted by demineralizing whole bone using a slightly more concentrated 2 percent hydrochloric acid for 72 hours, dissolving base-soluble contaminants using $.1 \mathrm{M}$ sodium hydroxide (24 hours before and after demineralization), and separating residual lipids with a mixture of methanol, chloroform, and water for 24 hours.

In phase I, collagen yields were found to be very low (between .8 and .2 percent) and eight samples yielded no collagen. Samples were analyzed for stable isotopes of carbon and nitrogen on a Finnigan
MAT Delta + mass spectrometer interfaced with a Carlo Erba gas analyzer in the Isotope Science Laboratory, University of Calgary. Given the low collagen yields, there was insufficient sample to measure nitrogen and therefore no data on stable isotopes of nitrogen. Thus, there are no $\mathrm{C} / \mathrm{N}$ data for evaluating the quality of the small amount of collagen that was recovered. Data on \%C range from 17 percent to 4 percent, much lower than the expected 30-44 percent found in well-preserved bone. Collagen yields in the phase II study were similarly insufficient for stable isotope analysis.

Since the stable carbon isotope data from collagen were severely limited and those obtained potentially affected by diagenesis, carbonate was isolated from bone mineral and tooth enamel. In phase I, approximately .5 grams of whole bone was ground in a mortar and pestle. Bone powder was treated with 2 percent sodium hypochlorite $(\mathrm{NaOCl})$ following the method of Lee-Thorp (1989). After five rinses, the samples were soaked in dilute acetic acid (.1M). After two hours, samples were rinsed under vacuum then freeze-dried. Samples were analyzed in Erlangen, Germany under the direction of Dr. Michael Joachimski. The carbonate powders were reacted with 100 percent phosphoric acid (density $>1.9$ ) (Wachter and Hayes 1985) at $75^{\circ} \mathrm{C}$ using a Kiel III online carbonate preparation line connected to a ThermoFinnigan 252 mass spectrometer. Results are reported in per mil relative to V-PDB. Reproducibility of replicate analyses of laboratory standards is better than \pm $.03 \%$. In phase II, apatite and enamel carbonate 
samples were similarly extracted using established techniques, with removal of organic components using sodium hypochlorite ( 24 hours for enamel, 72 hours for apatite), and of non-biogenic carbonates using buffered $1 \mathrm{M}$ acetic acid (24 hours). Apatite and enamel samples were analyzed with a Finnigan MAT Delta Plus instrument using a Kiel III device with 100 percent phosphoric acid at $90^{\circ}$ C (Tykot 2006).

Several types of analyses were conducted to test for diagenetic effects that could have altered $\delta^{13} \mathrm{C}$ signatures in the bone and tooth samples. Fourier transform infrared spectroscopy (FTIR) scans were carried out on phase I bone samples prepared for carbonate analysis. Crystallinity indices range between 3.95 and 2.74 and there is no correlation (Pearson's $r=.129$ ) between the crystallinity indices and the bone carbonate $\delta^{13} \mathrm{C}$. Both the indices $(<4.0)$ and the lack of a correlation suggest that the $\delta^{13} \mathrm{C}$ data from bone carbonate are providing dietary information. Although FTIR does not provide an infallible measure of diagenesis, it does offer a reasonable measure of increased crystallinity due to chemical alteration in the burial environment. Our data do not show evidence of increased crystallinity.

The $\delta^{18} \mathrm{O}$ values obtained in both phases of the analysis were also used to test for possible diagenetic effects on bone mineral. Although oxygen isotopes are thought to be more subject to diagenesis than stable carbon isotopes in bone, Wright and Schwarz (1996) have shown that oxygen isotope ratios may be helpful in detecting bone that has been altered in the burial environment. Pretreatment methods, as developed by LeeThorp (1989) and modified by others (e.g., Garvie-Lok et al. 2003), serve to eliminate adsorbed carbonate and organic matter. If some adsorbed carbonate remains, there will be enrichment of both ${ }^{13} \mathrm{C}$ and ${ }^{18} \mathrm{O}$, the heavier isotopes. If organic matter remains, there will be depletion of the heavier isotopes of both carbon and oxygen. Neither tooth enamel nor bone apatite shows a significant correlation between $\delta^{13} \mathrm{C}$ and $\delta^{18} \mathrm{O}$ values (Pearson's $r=.390 ; p=.121$; and Pearson's $r=-.095 ; p=.520$, respectively), which would be expected in the case of systematic contamination, although there is more variation in enamel $\delta^{18} \mathrm{O}$ than in bone carbonate. These data support the assertion that the $\delta^{13} \mathrm{C}$ values obtained in the study are providing information on diet rather than postmortem diagenesis.

Because tooth enamel is less susceptible to diagenesis than bone apatite (Lee-Thorp and Sponheimer 2003), a correlation coefficient also was calculated on matched bone apatite and enamel values from a subset of phase II individuals. A lack of correspondence of $\delta^{13} \mathrm{C}$ values between these tissue types would provide evidence that the bone apatite samples had been subject to diagenesis. However, the results are highly correlated (Pearson's $r=.852 ; p<.001)$, with a mean difference of $\pm 1.12 \%$, supporting the validity of the $\delta^{13} C_{a p}$ atite isotope data obtained in phase II of the analysis. These results were extrapolated to the phase I sample through a $t$-test comparing phase I and phase II $\delta^{13} C_{\text {apatite }}$ values for the Structural Gallinazo phase (the phase with the most $\delta^{13} \mathrm{C}_{\text {apatite }}$ values from phase I and phase II of the analysis): no significant differences were observed $(t=-.579 ; \mathrm{df}$ $=13 ; p=.572$ ).

The apatite and enamel data were analyzed in relation to several variables in order to identify patterning in the data. These included analyses to establish the validity of the stable isotope data, as well those focused on temporal phase, age, and sex. The age and sex variables were included to permit the identification of age and gender differences in diet that could speak to questions of how maize was being consumed and for what purpose (e.g., provisioning of male labor). Carbon isotope ratios are reported in tables and charts using the delta $(\delta)$ notation per mil $(\%)$ relative to the PDB and AIR standards respectively.

\section{Results}

As indicated above, attempts to obtain carbon and nitrogen stable isotope values from bone collagen were largely unsuccessful due to the low collagen content of the sampled bones. For this reason, the analysis focused almost exclusively on carbon isotopes of carbonate from bone apatite and tooth enamel. Two $\delta^{13} \mathrm{C}$ values obtained on bone collagen during the AMS dating analysis provide protein signatures for Salinar and Gallinazo phases useful for a preliminary assessment of the protein component of the diet (see Table 5).

The most significant pattern identified in the stable carbon isotope data is a change in $\delta^{13} C_{\text {apatite }}$ 
Table 5. Comparative $\delta^{13} \mathrm{C}$ Values and Diet for Archaeological Human Skeletal Samples. Sorted in Descending Order by $\delta^{13} \mathrm{C}_{\text {apatite }}$ Values.

\begin{tabular}{|c|c|c|c|c|}
\hline$\underline{\text { Sample }}$ & Diet: Protein/energy & $\delta^{13} \mathrm{C}_{\text {apatite }}$ & $\delta^{13} \mathrm{C}_{\text {collagen }}$ & $\Delta^{13} \mathrm{C}_{\mathrm{CA}-\mathrm{CO}} \% o$ \\
\hline Tierra del Fuego Inland $\mathrm{HG}^{\mathrm{a}}$ & $\mathrm{C}_{3} / \mathrm{C}_{3}$ & -15.5 & -20.5 & 5.0 \\
\hline Late Woodland Georgia ${ }^{\mathrm{b}}$ & $\mathrm{C}_{3} / \mathrm{C}_{3}$ & -14.9 & -19.4 & 4.5 \\
\hline Ontario Hunter-gatherers ${ }^{c}$ & $\mathrm{C}_{3} / \mathrm{C}_{3}$ & -13.1 & -19.8 & 6.7 \\
\hline Ontario Early Maize & $\mathrm{C}_{3} / \mathrm{C}_{3}, \mathrm{C}_{4}$ & -12.0 & -19.0 & 7.0 \\
\hline Southwestern Cape ${ }^{\mathrm{d}}$ & Marine $/ \mathrm{C}_{3}$ & -11.2 & -13.9 & 2.7 \\
\hline Tierra del Fuego Coast $\mathrm{HG}^{\mathrm{a}}$ & Marine/ $\mathrm{C}_{3}$ & -10.5 & -13.3 & 2.8 \\
\hline Cerro Oreja Guañape & $?$ & -10.3 & - & - \\
\hline Cerro Oreja Salinar ${ }^{\mathrm{e}}$ & $?$ & -10.0 & {$[-20.9]$} & [10.9] \\
\hline Cahokia High Status $^{\mathrm{f}}$ & $\mathrm{C}_{3} / \mathrm{C}_{4}$ & -9.1 & -17.5 & 8.4 \\
\hline Chiribaya Coastal Valley-C Alta ${ }^{g}$ & Marine $/ \mathrm{C}_{3}, \mathrm{C}_{4}$ & -9.1 & -13.1 & 4.0 \\
\hline Chiribaya Coastal Valley-C Baja ${ }^{g}$ & Marine, $\mathrm{C}_{3} / \mathrm{C}_{3}, \mathrm{C}_{4}$ & -8.8 & -13.3 & 4.5 \\
\hline Chiribaya Inland-Yaral ${ }^{g}$ & $\mathrm{C}_{3} / \mathrm{C}_{4}, \mathrm{C}_{3}$ & -8.4 & -14.0 & 5.6 \\
\hline Chiribaya Coast-San Geronimog & Marine/C $\mathrm{C}_{3}$ & -8.3 & -12.0 & 3.7 \\
\hline Cerro Oreja Gallinazo $^{\mathrm{e}}$ & $?$ & -7.4 & {$[-17.3]$} & [9.9] \\
\hline Illinois River Valley-Upland ${ }^{\mathrm{h}}$ & $\mathrm{C}_{3} / \mathrm{C}_{4}$ & -6.8 & -14.1 & 7.3 \\
\hline Ancón-Early Middle Horizon ${ }^{\mathrm{i}}$ & Marine, $\mathrm{C}_{4} / \mathrm{C}_{4}, \mathrm{C}_{3}$ & -6.0 & -12.3 & 5.6 \\
\hline American Bottom-Upland ${ }^{\mathrm{h}}$ & $\mathrm{C}_{3} / \mathrm{C}_{4}$ & -5.8 & -12.8 & 7.0 \\
\hline Ancón-Late Middle Horizon ${ }^{\mathrm{i}}$ & $\mathrm{C}_{4}$, Marine $/ \mathrm{C}_{4}, \mathrm{C}_{3}$ & -5.4 & -12.0 & 5.3 \\
\hline Ontario Maize Farmers ${ }^{\mathrm{c}}$ & $\mathrm{C}_{3} / \mathrm{C}_{4}$ & -5.1 & -11.5 & 6.4 \\
\hline American Bottom-Floodplain ${ }^{\mathrm{h}}$ & $\mathrm{C}_{3} / \mathrm{C}_{4}$ & -5.1 & -11.1 & 6.0 \\
\hline Grasshopper Pueblo, SW & $\mathrm{C}_{3} / \mathrm{C}_{4}$ & -4.9 & -10.0 & 5.1 \\
\hline Cahokia Low Status $^{\mathrm{f}}$ & $\mathrm{C}_{3} / \mathrm{C}_{4}$ & -4.2 & -16.4 & 12.2 \\
\hline \multicolumn{5}{|c|}{ a Yesner et al. 2003.} \\
\hline \multicolumn{5}{|c|}{ b Tucker 2002, based on Kellner and Schoeninger 2009: Table 3.} \\
\hline \multicolumn{5}{|c|}{${ }^{\mathrm{c}}$ Harrison and Katzenberg 2003.} \\
\hline \multicolumn{5}{|c|}{ d Lee-Thorp et al. 1989, based on Kellner and Schoeninger 2007: Table 3.} \\
\hline \multirow{2}{*}{\multicolumn{5}{|c|}{$\begin{array}{l}\text { e Current study. Collagen } \delta^{13} \mathrm{C} \text { values for Salinar and Gallinazo were obtained during AMS analysis. Indicated in brackets, } \\
\text { each represents a single individual, not mean values for the sample. }\end{array}$}} \\
\hline & & & & \\
\hline \multicolumn{5}{|c|}{ g Tomczak 2003.} \\
\hline \multicolumn{5}{|c|}{${ }^{\mathrm{h}}$ Hedman et al. 2002, based on Kellner and Schoeninger 2009: Table 3.} \\
\hline \multicolumn{5}{|c|}{$\begin{array}{l}{ }^{\mathrm{i}} \text { Slovak and Paytan 2011: Table } 1 . \Delta^{13} \mathrm{C}_{\mathrm{CA}-\mathrm{CO}} \text { values based on subset of samples for which both carbonate and collagen val- } \\
\text { ues were available. }\end{array}$} \\
\hline
\end{tabular}

values between pre-Gallinazo and Gallinazo phase samples (Table 4; Figure 3). The pattern is not one of gradual change, however, but rather is a marked shift in mean $\delta^{13} \mathrm{C}_{\text {apatite }}$ values of $2.5 \%$ o between the Salinar and Pre-Structural Gallinazo phases $(t=$ $-4.518 ; d f=18 ; p<.001)$. There are no significant differences between Guañape and Salinar $\delta^{13} \mathrm{C}_{\text {apatite }}$ values $(t=-.359 ; d f=10 ; p=.727)$, PreStructural and Structural Gallinazo $\delta^{13} \mathrm{C}_{\text {apatite }}$ values $(t=-.574 ; d f=25 ; p=.571)$, or Structural and PostStructural Gallinazo $\delta^{13} \mathrm{C}_{\text {apatite }}$ values $(t=-.153 ; d f$ $=19 ; p=.880)$. These data indicate that a change in diet toward ${ }^{13} \mathrm{C}$ enriched foods occurred between the Salinar and early Gallinazo phase use of the cemetery at Cerro Oreja, and suggest a hiatus in use of the cemetery between the two phases. The two $\delta^{13} \mathrm{C}$ values obtained from the AMS dating analysis of bone collagen (Table 5) suggest a similar shift of 3.6\%o (2.7\% o for apatite values) between the Salinar and Structural Gallinazo phases.

An age-based comparison of diet produced mixed results. A correlation analysis examining the relationship between age (for individuals 12 and older) and $\delta^{13} \mathrm{C}_{\text {apatite }}$ values in the Gallinazo phase component of the sample found no significant correlation between these two variables (Spearman's $r=.163 ; p=.357 ; n=34$ ). People's diets during this time period do not appear to have shifted with respect to dietary ${ }^{13} \mathrm{C}$ from adolescence to old age. Although a strong positive correlation between $\delta^{13} \mathrm{C}_{\text {enamel }}$ and $\delta^{13} \mathrm{C}_{\text {apatite }}$ values (Pearson's $r=.852$; $p<.001 ; n=14$ paired samples) indicates that diet 


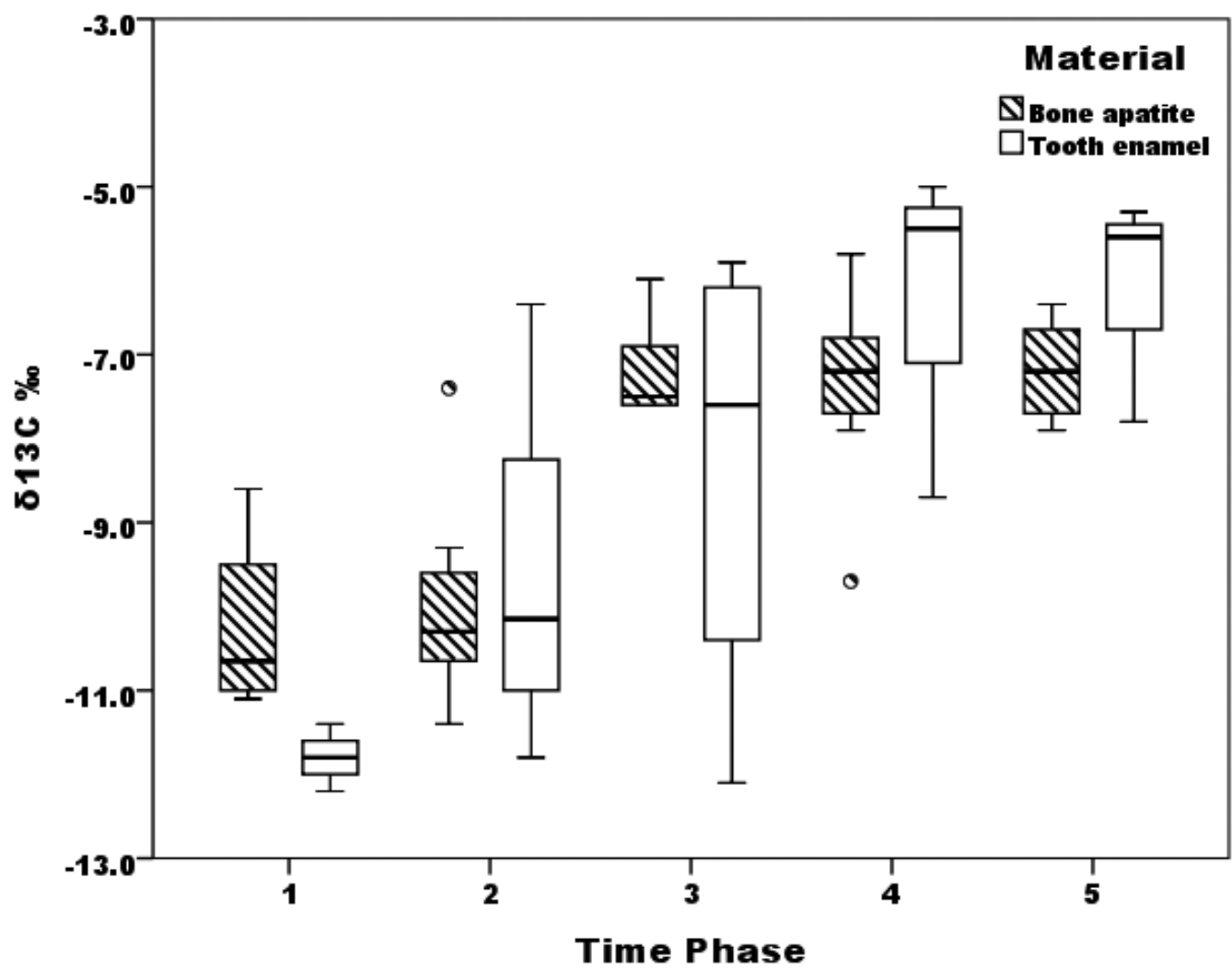

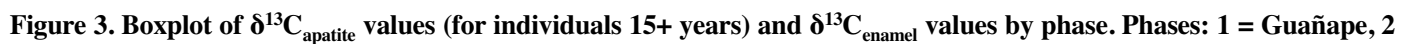
= Salinar, 3 = Pre-Structural Gallinazo, 4 = Structural Gallinazo, 5 = Post-Structural Gallinazo.

also did not differ significantly between the toothforming years and adulthood, a plot of adult apatite values and enamel values reveals some time sensitive and potentially meaningful age differences in diet (Figure 3). In the Guañape phase, enamel values are less enriched in the heavier isotope than adult apatite values. Enamel values in the later Gallinazo phase samples (Structural and Post-Structural), on the other hand, show the opposite pattern and tend to be more enriched in ${ }^{13} \mathrm{C}$ than adult apatite values. Salinar and Pre-Structural Gallinazo phase values overlap. Although tooth enamel values can show much greater variance than apatite values due to seasonal and annual differences reflected in incremental enamel structure (Eerkins et al. 2011; Wright and Schwarcz 1998), the $\delta^{13} \mathrm{C}_{\text {enamel }}$ values nonetheless suggest that the diet of subadults (6 months-12 years) differed from that of adults in some phases and that the subadult diet came to be relatively more enriched in ${ }^{13} \mathrm{C}$ during the Gallinazo phase.
Figure 4 showing $\delta^{13} C_{\text {apatite }}$ values by sex reveals some differences between males and females by time period, with females having more ${ }^{13} \mathrm{C}$ enriched values in the Guañape and Salinar phases, and males having more ${ }^{13} \mathrm{C}$ enriched values during the Gallinazo phase. While this patterning is suggestive of dietary differences between males and females, these differences are not statistically significant, either for the sample as a whole $(t=-.170$; $d f=42 ; p=.866)$, or for the Gallinazo phase $(t=$ $.159 ; d f=31 ; p=.875)$.

The single $\delta^{13} \mathrm{C}$ apatite value from an individual buried with a highland Recuay vessel, obtained for a male from the Structural Gallinazo sample, is more enriched in carbon-13 $\left(\delta^{13} \mathrm{C}_{\text {apatite }}=-6.5 \%\right.$ ) than 80 percent of the values obtained for this phase (mean $\delta^{13} \mathrm{C}_{\text {apatite }}=-7.2 \%$ ). However, this value falls within one standard deviation of the mean, suggesting that the diet of this male did not differ significantly from others of this period. 


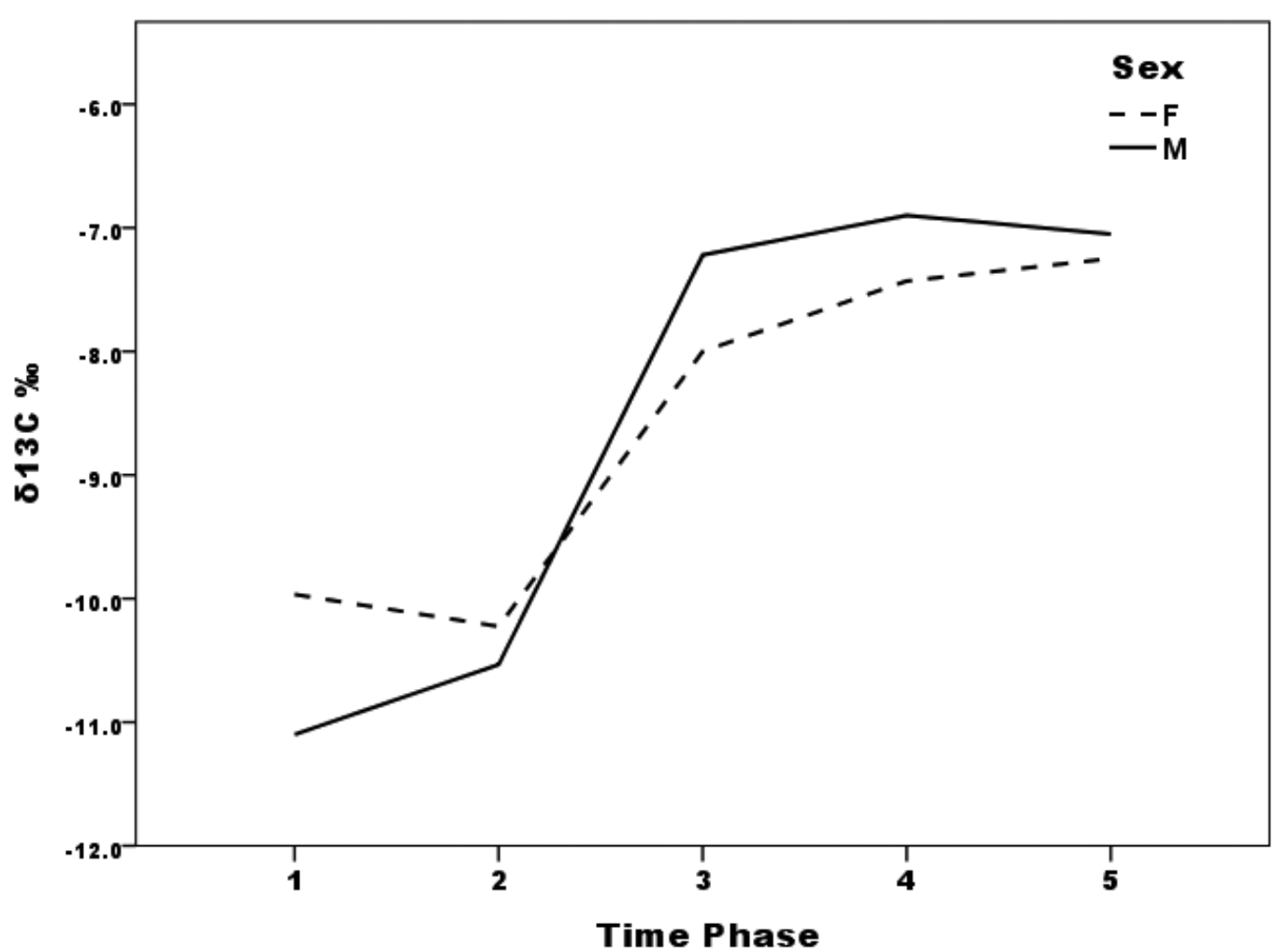

Figure 4. Sex differences in mean $\delta^{13} C_{\text {apatite }}$ values by phase. Phases: $1=$ Guañape, 2 = Salinar, $3=$ Pre-Structural Gallinazo, 4 = Structural Gallinazo, 5 = Post-Structural Gallinazo.

\section{Discussion}

The most notable pattern evident in the stable isotope data is significant enrichment in $\delta^{13} \mathrm{C}_{\text {apatite }}$ values in the Gallinazo phase at Cerro Oreja. This enrichment could have occurred in three ways: (1) the Gallinazo phase occupants of Cerro Oreja could have increased their production of maize; (2) they could have intensified their use of marine resources; or (3) they could have intensified their production and use of maize and marine resources, respectively. Several lines of evidence suggest that this shift marks an agricultural transition toward maize intensification.

As noted above, archaeological investigations in the Moche Valley suggest an intensification of irrigation agriculture from the Guañape through Moche phases (Billman 2002). During the Guañape phase, settlement in the Moche Valley expanded as people moved inland and began canal construction (Billman 1996, 2002). Zooarchaeological and paleobotanical data from both coastal and inland sites suggests a diet with a protein component dominated by marine resources, but that included substantial terrestrial animal use and a wide variety of cultigens (Pozorski and Pozorski 1979). In the Salinar phase the irrigation system was expanded through new canal construction, increasing lands under cultivation by 73 percent from the preceding phase (Billman 2002). Zooarchaeological remains from Cerro Arena suggest a decrease in the use of marine resources during the Salinar phase (Pozorski 1979).

During the Gallinazo phase, much of the population of the valley aggregated at the valley neck at or near Cerro Oreja and on the coast at the site of Pampa Cruz, located at the modern community of Huanchaco (Billman 1996, 2002). Excavations of Gallinazo phase sites are very limited and no studies of Gallinazo phase food remains have been conducted. However, $\delta^{13} \mathrm{C}_{\text {apatite }}$ values show a significant enrichment in ${ }^{13} \mathrm{C}$, indicating a shift in food sources relative to the Salinar phase (Tables 3 and 5, Figure 3). Although this shift could represent a 
significant increase in the use of marine resources, perhaps through trade with Pampa Cruz, this seems unlikely to be the main source of ${ }^{13} \mathrm{C}$ enrichment given the location of Cerro Oreja and its population of perhaps more than 7,000 at the intake canals that supported the irrigation of thousands of hectares of high-quality arable land.

Comparisons between Cerro Oreja mean $\delta^{13} \mathrm{C}_{\text {ap- }}$ atite values and those obtained for highly controlled diets in experimental animal studies offer one mechanism for interpreting the apatite data (Table 1). The normalized mean Gallinazo $\delta^{13} \mathrm{C}_{\text {apatite }}$ value is $-8.9 \%$ o $(-7.4 \% o-1.5 \%)$. This value is nearest to the record for a pig $(-9.0 \%$ ) that consumed a diet of 14 percent $\mathrm{C}_{3}$ protein and 50 percent maize $\left(\delta^{13} C_{\text {diet }}=-18.0\right)$ (Howland et al. 2003). The next closest value reflects a diet of 20 percent marine fish and 35 percent maize (rat, $-8.6 \%$; $\delta^{13} \mathrm{C}_{\text {diet }}=$ -18.3) (Jim et al. 2004). Of the two animal samples, the closest match when body size and $\delta^{13} \mathrm{C}_{\text {collagen }}$ values are also considered is the first. Although a single, nonhuman animal value is not definitive, it offers insight into which dietary emphasis may be indicated.

Comparisons between Cerro Oreja mean $\delta^{13} C_{\text {apatite }}$ values and those from archaeological human skeletal series with known diets provide another basis for interpreting the stable isotope results (Table 5). In this case, the two closest values to the Gallinazo mean $\delta^{13} \mathrm{C}_{\text {apatite }}$ value of $-7.4 \%$ o derive from the marine dependent coastal prehistoric population of the Chiribaya site of San Gerónimo on the south coast of Peru $(-8.3 \%$; Tomczak 2003:269) and a Mississippian population of maize farmers from the uplands of the Illinois River valley $\left(\delta^{13} C_{\text {apatite }}=-6.8 \%\right.$; Hedman et al. 2002). The San Gerónimo value probably demarcates the upper $\delta^{13} \mathrm{C}_{\text {apatite }}$ limits for a population obtaining their protein from sea resources and energy from $\mathrm{C}_{3}$ plant foods in coastal Peru. The Gallinazo sample from Cerro Oreja is $.9 \%$ more enriched in ${ }^{13} \mathrm{C}$ than this sample and is closer in all three $\delta^{13} \mathrm{C}$ values $\left(\delta^{13} \mathrm{C}_{\text {apatite }}, \delta^{13} \mathrm{C}_{\text {collagen }}\right.$ and $\left.\Delta^{13} \mathrm{C}_{\mathrm{CA}-\mathrm{CO}}\right)$ to the Illinois upland maize farmers than to the $\mathrm{San}$ Gerónimo coastal population, suggesting $\mathrm{a}_{4}$ food component to the diet. The next closest apatite values are from the Chiribaya site of Yaral $(-8.4 \%$; Tomczak 2003:269) and the Middle Horizon site of Ancón on the central coast ( $-6.0 \%$; Slovak and Paytan 2011:257). At Yaral, collagen and apatite values indicate a reliance on terrestrial animal and plant foods, including maize. At Ancón, both marine resources and maize were important in the diet, but intensive maize use appears to have shifted the Ancón apatite values to a mean $\delta^{13} \mathrm{C}$ value $2.3 \%$ o more positive than at San Gerónimo (-8.3\%o) (Table 5). It seems unlikely that the noncoastal population at Cerro Oreja was as dependent on marine resources as either San Gerónimo or Ancón, suggesting that ${ }^{13} \mathrm{C}$ enrichment at Cerro Oreja was primarily, though not necessarily exclusively, due to maize consumption.

Dental data provide some of the most compelling supporting evidence for maize as the cause of ${ }^{13} \mathrm{C}$ enrichment during the Gallinazo phase at Cerro Oreja. As noted above, several indicators of dental disease show a significant increase from Salinar to Gallinazo phases, indicating that the diet became more cariogenic and that foods may have become more heavily processed. The frequency of carious adult teeth increased from 17 percent among females during the Salinar to 32 percent during the Pre-structural Gallinazo phase, and among males from 22 percent to 28 percent during the same period (Gagnon and Wiesen 2011:Table 3). Among children a similar trend was found, with the Salinar rate of 6 percent carious deciduous teeth increasing to 12 percent during the Pre-Structural Gallinazo phase (Gagnon 2006:155). During this same period dental abscessing increased from 10 percent to 14 percent among adult females and from 6 percent to 23 percent among adult males (Gagnon 2006:161), while antemortem tooth loss rates increased from 13 percent to 18 percent among adult females and 7 percent to 17 percent among adult males (Gagnon 2006:166)

Although not as definitive as the evidence of dental disease, patterns of dental trauma are consistent with the proposed shift in diet. The consumption of foods containing grit and other hard particles can result in enamel chipping (Milner and Larsen 1991; Turner and Cadien 1969). While chipping on anterior teeth most commonly results from use of the teeth as tools (Hutchinson 2002), trauma to posterior teeth is more often caused by chewing foods with grit and other inclusions (Milner and Larsen 1991). In particular, foragers have been shown to have higher rates of chipping than food producers as a result of more grit in the diet (Turner 1993). Shellfish also contain grit and sand, and 
shellfish consumption can therefore contribute to this type of dental damage (Sealy and van der Merwe 1998). At Cerro Oreja, rates of chipping among all teeth ranged from 25 percent to 35 percent in adults, with posterior teeth more often chipped than anterior teeth (Gagnon 2006:185). The rate of chipped adult teeth was highest during the Salinar phase (35 percent) and lowest during the Pre-Structural Gallinazo phase (25 percent), which suggests a shift from more grit-laden foods such as shellfish to more highly processed foods such as maize gruels or stews.

Collectively, these data indicate that the null hypothesis of a lack of change in the subsistence regime in the Gallinazo phase can be rejected. Instead, the data provide support for hypothesis $\mathrm{H}_{\mathrm{A}}$, of an intensification of maize agriculture during the Gallinazo phase in the Moche Valley. It is difficult to say what the mode of maize consumption was or how it might have changed during the period represented by the human remains from Cerro Oreja. Limited data on $\delta^{13} \mathrm{C}$ values for matched bone apatite and tooth enamel from adult skeletons suggest that the adult diet was more enriched in ${ }^{13} \mathrm{C}$ than the diet of subadults during the Guañape phase, which may reflect greater consumption of marine foods by adults at that time (Figure 3). In the Salinar and Pre-Structural Gallinazo phases, the $\delta^{13} \mathrm{C}$ values from bone apatite and tooth enamel were similar within each respective sample, albeit with greater variability evident among tooth samples due to the nature of tooth enamel formation and sampling. In the last two subphases of the Gallinazo phase, adults were consuming less ${ }^{13} \mathrm{C}$ enriched foods than subadults, suggesting that maize had become an important food for the young ( 6 months-12 years), perhaps in particular for porridges that sustained them during the weaning years (see Slovak and Paytan 2011:262). Unfortunately, without information on specific tooth types sampled in the enamel study (only tooth fragments of unknown type were sampled) this hypothesis cannot be tested. Clearly adults were also consuming maize, but to what extent this may have been in the form of chicha de maíz awaits further clarification.

\section{Concluding Remarks}

The shift in subsistence that heralded the Gallinazo phase ca. A.D. 1 did not immediately lead to the development of a regional political economy, as the Southern Moche state probably did not fully emerge in the Moche Valley until the A.D. 200s or perhaps even in the A.D. 300s (Billman 2010; Quilter and Castillo 2010). However, what these results indicate is that key changes occurred in the domestic and political economies well in advance of the dramatic expansion of the Moche political economy in the A.D. 300s. Our data suggest that farmers may have transitioned to the intensive production of maize in the Gallinazo phase. This intensification of production required farming families to invest more labor in cultivation, probably through such practices as shorter fallow periods and use of fertilizers. Generally speaking, peasant farmers intensify production because of population pressure, market demands, or tribute demands of the political economy (Netting 1993). Given the absence of any evidence of population growth in the valley (Billman 1996; Gagnon and Wiesen 2011) or changing market conditions during the Gallinazo phase (Billman 1996, 1997), this shift in diet and agricultural practices may have been caused by the increased demands of the Cerro Oreja polity. If this was the case, then this signals a fundamental change in the relationship between farmers and rulers. In short the Gallinazo phase economic shift may have established the political economic relationships that were key to the dramatic expansion of the power of Moche leaders in the Middle Moche phase. In this sense, Castillo's (2009:227) prediction that increased agricultural productivity provided the necessary preconditions for the political developments in the Moche period finds support in the archaeological record of the Moche Valley, where the greatest monuments to Moche power and ingenuity were first constructed.

Additional work in the domestic sector at Cerro Oreja is needed to further elucidate the economic transition identified in this study, particularly as it pertains to agricultural intensification, the production and use of maize products, and the acquisition and consumption of marine resources. Comparative stable isotope research on the Pampas Cruz population is also needed to clarify the nature of the economic relationship between Cerro Oreja and this contemporaneous coastal community, a relationship that could have played a pivotal role in the development of the political economy that ultimately gave rise to the Southern Moche state. 
Acknowledgments. Permission to conduct research on the human skeletal remains from Cerro Oreja was granted through a convenio agreement between the Instituto Nacional de Cultura, the UNC-Chapel Hill, and Utah State University. The authors would like to thank Ana Maria Hoyle, César A. Gálvez Mora and Jesús Briceño Rosario at the Instituto Nacional de Cultura-La Libertad, for their support of the Bioarchaeology of Moche Origins Project. We would also like to thank Christopher A. Pool, Gabriela Uruñuela y Ladrón de Guevara, and three anonymous reviewers for their constructive comments on an earlier version of this manuscript. We are grateful to Michael D. School for creating the sample map. This research was funded by a Utah State University New Faculty Research Grant, The Wenner Gren Foundation (grant no. 6623 to Patricia Lambert and grant no. 7337 to Brian Billman), the University of North Carolina at Chapel Hill Institute for Latin American Studies, Sigma Xi, the UNC-CH Graduate College (to Celeste Gagnon), and the National Science Foundation (grant no. 0225011 to Brian Billman and Celeste Gagnon).

\section{References Cited}

Ambrose, Stanley H., Jane E. Buikstra, and Harold W. Krueger 2003 Gender and Status Differences in Diet at Mound 72, Cahokia, Revealed by Isotopic Analysis of Bone. Journal of Anthropological Archaeology 22:217-226.

Ambrose, Stanley H., and Lynette Norr

1993 Experimental Evidence for the Relationship of the Carbon Isotope Ratios of Whole Diet and Dietary Protein to Those of Bone Collagen and Carbonate. In Prehistoric Human Bone: Archaeology at the Molecular Level, edited by Joseph B. Lambert and Gisela Grupe, pp. 1-38. Springer-Verlag, Berlin.

Bawden, Garth

1995 The Structural Paradox: Moche culture as Political Ideology. Latin American Antiquity 6:255-273.

1996 The Moche. Blackwell Publishers, Cambridge, Massachusetts.

Bernier, Hélène

2010 Craft Specialists at Moche: Organization,Affiliations, and Identities. Latin American Antiquity 21:22-43.

Billman, Brian R.

1996 The Evolution of Prehistoric Political Organizations in the Moche Valley, Peru. Unpublished Ph.D. dissertation, Department of Anthropology, University of California, Santa Barbara.

1997 Population Pressure and the Origins of Warfare in the Moche Valley, Peru. In Integrating Archaeological Demography: Multidisciplinary Approaches to Prehistoric Populations, edited by Richard R. Paine, pp. 285-310. Occasional Paper 24. Center for Archaeological Investigations, University of Southern Illinois, Carbondale.

1999 Reconstructing Prehistoric Political Economies and Cycles of Political Power in the Moche Valley, Peru. In Settlement Pattern Studies in the Americas: Fifty Years Since Virú, edited by BrianR. Billman and Gary M. Feinman, pp. 131-159. Smithsonian Institution Press, Washington, D.C.

2002 Irrigation and the Origins of the Southern Moche State on the North Coast of Peru. Latin American Antiquity $13: 371-400$.
2010 How Moche Rulers Came to Power. In New Perspectives on Moche Political Organization, edited by Jeffery Quilter and Luis Jaime Castillo Butters, pp. 181-200. Dumbarton Oaks Pre-Columbian Symposia and Colloquia, Washington, D.C.

Bird, Robert McK., and Junius B. Bird

1980 Gallinazo Maize from the Chicama Valley, Peru. American Antiquity 45:325-332.

Bourget Steve

1996 Excavaciones en la Plaza 3a y en la Plataforma II de la Huaca de la Luna durante 1966. In Investigaciones en la Huaca de la Luna 1996, edited by Santiago Uceda C., Elías Mujica B., and Richard Morales G., pp. 43-64. Facultad de Ciencias Sociales, Universidad Nacional de La Libertad, Trujillo.

2001 Children and Ancestors: Ritual Practices at the Moche Site of Huaca de la Luna, North Coast Peru. In Ritual Sacrifice in Ancient Peru, edited by Elizabeth P. Benson, and Anita G. Cook, pp. 93-118. University of Texas Press, Austin.

Boutton, Thomas W.

1991 Stable Carbon Isotope Ratios of Natural Materials II: Atmospheric, Terrestrial, Marine and Freshwater Environments. In Carbon Isotope Techniques, edited by David C. Coleman, and Brian Fry, pp. 173-186. Academic Press, San Diego.

Bray, Tamara L.

2009 The Role of Chicha in Inca State Expansion: A Distributional Study of Inca Aríbalos. In Drink, Power, and Society in the Andes, edited by Justin Jennings and Brenda J. Bowser, pp. 108-132. University Press of Florida, Gainesville.

Brennan, Curtiss T.

1978 Investigations at Cerro Arena, Peru: Incipient Urbanism on the Peruvian North Coast. Unpublished Ph.D. Dissertation, Department of Anthropology, University of Arizona, Tucson.

1980a Cerro Arena: Early Cultural Complexity and Nucleation in North Coastal Peru. Journal of Field Archaeology 7:1-22.

1980b Cerro Arena: Rise of the Andean Elite. Archaeology 33:6-13.

Briceño Rosario, Jesús, Brian R. Billman, and Jennifer Ringberg

2006 Proyecto Arqueológico Cerro Oreja Valle de Moche, Informe Final, Tomo 1 Temporada 2005. La Libertad Dirección Regional de Cultura, Trujillo.

Buikstra, Jane E., and George R. Milner

1991 Isotopic and Archaeological Interpretations of Diet in the Central Mississippi Valley. Journal of Archaeological Science 18:319-329.

Burger, Richard L., and Nikolaas van der Merwe

1990 Maize and the Origin of Highland Chavin Civilization: An Isotopic Perspective. American Anthropologist 92:85-95.

Carcelén, José

1995 Rescate arqueológico flanco norte y arenales al oeste de Cerro Oreja. Informe de Entrega de Obra, Tomo II, Vol. IV. La Libertad Dirección Regional de Cultura, Trujillo.

Castillo Butters, Luis Jaime

2009 Gallinazo, Vicús, and Moche in the Development of Complex Societies Along the North Coast of Peru. In Gallinazo: An Early Cultural Tradition on the North Coast, edited by Jean-François Millaire and Magali Morlion, pp. 223-231. Cotsen Institute of Archaeology Press, University of California, Los Angeles. 
2010 Moche Politics in the Jequetepeque Valley. In New Perspectives on Moche Political Organization, edited by Jeffery Quilter, and Luis Jaime Castillo Butters, pp. 83-109. Dumbarton Oaks, Washington, D.C.

Chauchat, Claude, Jean Guffroy, and Thomas Pozorski

2006 Excavations at Huaca Herederos Chica, Moche Valley, Peru. Journal of Field Archaeology 31:233-250.

Cohen, Mark N., and George J. Armelagos (editors)

1984 Paleopathology at the Origins of Agriculture. Academic Press, New York.

DeNiro, Michael

1988 Marine Food Sources for Prehistoric Coastal Peruvian Camelids: Evidence and Implications. In Economic Prehistory of the Central Andes, edited by Elizabeth S. Wing and Jane C. Wheeler, pp. 119-129. BAR International Series 427. British Archaeological Reports, Oxford.

Donnan, Christopher B., and Carol J. Mackey

1978 Ancient Burial Patterns of the Moche Valley, Peru. University of Texas Press, Austin.

Eerkins, Jelmer W., Ada G. Berget, and Eric J. Bartelink

2011 Estimating Weaning and Early Childhood Diet from Serial Micro-samples of Dentin Collagen. Journal of Archaeological Science 38:3101-3111.

Ezzo, Joseph A.

1993 Human Adaptation at Grasshopper Pueblo, Arizona: Social and Ecological Perspectives. International Monographs in Prehistory. Museum of Anthropology,Ann Arbor, Michigan.

Finucane, Brian Clifton

2007 Mummies, Maize, and Manure: Multi-Tissue Stable Isotope Analysis of Late Prehistoric Human Remains from the Ayacucho Valley, Perú. Journal of Archaeological Science 34:2115-2124.

Finucane, Brian Clifton, Patricia Maita Agurto, and William H. Isbell

2006 Human and Animal Diet at Conchopata, Peru: Stable Isotope Evidence for Maize Agriculture and Animal Management Practices During the Middle Horizon. Journal of Archaeological Science 33:1766-1776.

Gagnon, Celeste Marie

2006 Daily Life and the Development of the State in the Moche Valley of North Coastal Peru: a Bioarchaeological Analysis. Ph.D. dissertation, University of North Carolina at Chapel Hill. University Microfilms, Ann Arbor.

Gagnon, Celeste Marie, and Chris Wiesen

2011 Using General Estimating Equations to Analyze Oral Health in the Moche Valley of Perú. International Journal of Osteoarchaeology, in press.

Garvie-Lok, Sandra J., Tamara L. Varney, and M. Anne Katzenberg

2003 Preparation of Bone Carbonate for Stable Isotope Analysis: The Effects of Treatment Time and Acid Concentration. Journal of Archaeological Science 31:763-776.

Haas, Jonathan

1987 The Exercise of Power in Early Andean State Development. In The Development and Origins of the Andean State, edited by Jonathan Haas, Sheila Pozorski, and Thomas Pozorski, pp.31-35. Cambridge University Press, Cambridge.

Harrison, Roman G., and M. Anne Katzenberg

2003 Paleodiet Studies Using Stable Carbon Isotopes from Bone Apatite and Collagen: Examples from Southern Ontario and San Nicolas Island, California. Journal of Anthropological Archaeology 22:227-244.

Hastings, Charles M., and Michael E. Moseley

1975 The Adobes of Huaca del Sol and Huaca de la Luna. American Antiquity 40:196-203.
Hastorf, Christine A.

1985 Dietary Reconstruction in the Andes: A New Archaeological Technique. Anthropology Today 1:6:19-21.

Hastorf, Christine A., and Michael J. DeNiro

1985 Reconstruction of Prehistoric Plant Production and Cooking Practices by a New Isotopic Method. Nature 315:429-431.

Hastorf, Christine A., and Sissel Johannessen

1993 Pre-Hispanic Political Change and the Role of Maize in the Central Andes of Peru. American Anthropologist 95:115-138.

Hayashida, Frances

2009 Chicha Histories: Pre-Hispanic Brewing in the Andes and the Use of Ethnographic and Historical Analogues. In Drink, Power, and Society in the Andes, edited by Justin Jennings and Brenda Bowser, pp. 232-256.University of Florida Press, Gainesville.

Hedges, Robert E. M., John G. Clement, C. David L. Thomas, and Tamsin C. O'Connell

2007 Collagen Turnover in the Adult Femoral Mid-Shaft: Modeled From Anthropogenic Radiocarbon Tracer Measurements. American Journal of Physical Anthropology 133: 808-816.

Hedman, Kristin, Eve A. Hargrave, and Stanley H. Ambrose

2002 Late Mississippian Diet in the American Bottom: Stable Isotope Analyses of Bone Collagen and Apatite. Midcontinental Journal of Archaeology 27:237-271.

Hillson, Simon

1996 Dental Anthropology. Cambridge University Press, Cambridge.

Howland, Mark R., Lorna T. Corr, Suzanne M. Young, Vicky Jones, Susan Jim, Nikolaas van der Merwe, Alva D. Mitchell, and Richard P. Evershed

2003 Expression of the Dietary Isotope Signal in the Compound-specific $\delta^{13} \mathrm{C}$ Values of Pig Bone Lipids and Amino Acids. International Journal of Osteoarchaeology 13:54-65.

Hutchinson, Dale L.

2002 Foraging, Farming, and Coastal Biocultural Adaptation in Late Prehistoric North Carolina. University of Florida Press, Gainesville.

Jim, Susan, Stanley Ambrose, and Richard P. Evershed

2004 Stable Carbon Isotopic Evidence for Differences in the Dietary Origin of Bone Cholesterol, Collagen, and Apatite: Implications for Their Use in Paleodietary Reconstruction. Geochim Cosmochim Acta 68:61-72.

Johannessen, Sissel, and Christine A. Hastorf (editors)

1995 Corn and Culture in the Prehistoric New World. Westview Press, Boulder.

Katzenberg, M. Anne

1989 Stable Isotope Analysis of Archaeological Faunal Remains from southern Ontario. Journal of Archaeological Science 16:319-329.

1993 Case Studies: Lessons from the Past-Challenges of the Future. In Investigation of Ancient Human Tissue: Chemical Analysis in Anthropology, edited by Mary K. Sanford, pp. 335-360. Gordon and Breach Science Publishers, Langhorne, Pennsylvania.

Katzenberg, M. Anne, Olga Goriunova, and Andrzej Weber 2009 Paleodiet Reconstruction of Bronze Age Siberians from the Mortuary Site of Khuzhir-Nuge XIV, Lake Baikal. Journal of Archaeological Science 36:663-674.

Katzenberg, M. Anne, Henry P. Schwarcz, Martin Knyf, and F. Jerome Melbye

1995 Stable Isotope Evidence for Maize Horticulture and Paleodiet in Southern Ontario, Canada. American Antiquity 60:335-350. 
Kelley, Marc A., and Clark Spencer Larsen (editors) 1991 Advances in Dental Anthropology. Wiley-Liss, New York.

Kellner, Corina M., and Margaret J. Schoeninger

2007 A Simple Carbon Isotope Model for Reconstructing Prehistoric Human Diet. American Journal of Physical Anthropology 133:1112-1127.

2008 Wari's Imperial Influence on Local Nasca Diet: The Stable Isotope Evidence. Journal of Anthropological Archaeology 27:226-243.

2009 Erratum: Corina M. Kellner and Margaret J. Schoeninger (2007) A Simple Carbon Isotope Model for Reconstructing Prehistoric Human Diet. American Journal of Physical Anthropology 133:1112-1127. American Journal of Physical Anthropology 140:395-398.

Knudson, Kelly J., Arthur E. Aufderheide, and Jane E. Buikstra

2007 Seasonality and Paleodiet in the Chiribaya Polity of Southern Peru. Journal of Archaeological Science 34:451-462.

Krigbaum, John

2003 Neolithic Subsistence Patterns in Northern Borneo Reconstructed with Stable Carbon Isotopes of Enamel. Journal of Anthropological Archaeology 22:292-304.

Krueger, Harold W., and Charles H. Sullivan 1984 Models for Carbon Isotope Fractionation Between Diet and Bone. In Stables Isotopes in Nutrition, edited by Judith R. Turnlund and Phyllis E. Johnson, pp. 205-220. American Chemical Society Symposium Series, Washington, D.C.

Lambert, Patricia M.

2000 Life on the Periphery: Health in Farming Communities of Interior North Carolina and Virginia. In Bioarchaeological Studies of Life in the Age of Agriculture: A View from the Southeast, edited by Patricia M. Lambert, pp. 168-194. University of Alabama Press, Tuscaloosa.

Larsen, Clark Spencer

1997 Bioarchaeology: Interpreting Behavior from the Human Skeleton. Cambridge University Press, Cambridge.

Larsen, Clark Spencer, Margaret J. Schoeninger, Nikolaas J. van der Merwe, and Julia A. Lee-Thorp

1992 Carbon and Nitrogen Stable Isotopic Signatures of Human Dietary Change in the Georgia Bight. American Journal of Physical Anthropology 89:192-214.

Lee-Thorp, Julia A.

1989 Stable Carbon Isotopes in Deep Time: The Diets of Fossil Fauna and Hominids. Unpublished Ph.D. Dissertation. University of Cape Town, South Africa.

Lee-Thorp, Julia A., and Matt Sponheimer

2003 Three Case Studies Used to Reassess the Reliability of Fossil Bone and Enamel Isotope Signals for Paleodietary Studies. Journal of Anthropological Archaeology 22:208-216.

Lukacs, John R.

1989 Dental Paleopathology: Methods for Reconstruction Dietary Patterns. In Reconstruction of Life from the Skeleton, edited by Yasar M. Iscan, and Kenneth A. R. Kennedy, pp. 261-286. Allen R Liss Inc., New York.

Millaire, Jean-François

2002 Moche Burial Patterns: An Investigation into Prehispanic Social Structure. BAR International Series 1066. British Archaeological Reports, Oxford.

Milner, George R., and Clark Spencer Larsen

1991 Teeth as Artifacts of Human Behavior: Intentional Mutilation and Accidental Modification. In Advances in Dental Anthropology, edited by Marc A. Kelley and Clark Spencer Larsen, pp. 357-378. Wiley-Liss, New York.
Moore, Jerry D.

1989 Pre-Hispanic Beer in Coastal Peru: Technology and Social Context of Prehistoric Production. American Anthropologist 91:682-695.

Moseley, Michael E.

1974 Organizational Preadaptation to Irrigation: The Evolution of Early Water-Management Systems in Coastal Peru. In Irrigation's Impact on Society, edited by Robert McCormick Adams, Theodore E. Downing and McGuire Gibson, pp. 77-82. Anthropological Papers of the University of Arizona No. 25. University of Arizona, Tucson. 1975 Prehistoric Principles of Labor Organization in the Moche Valley, Peru. American Antiquity 40:191-196.

Moseley, Michael E., and Eric E. Deeds

1982 The Land in Front of Chan Chan: Agrarian Expansion, Reform, and Collapse in the Moche Valley. In Chan Chan: Andean Desert City, edited by Micheel E. Moseley and Kent C. Day, pp. 25-54. University of New Mexico Press, Albuquerque.

Mujica, Barreda Elías

1975 Excavaciones arqueológicas en Cerro Arena: un sitio Formativo Superior en el Valle del Moche, Perú. Unpublished thesis, Pontificia Universidad Católica del Perú, Lima.

Netting, Robert McC.

1993 Smallholders, Householders: Farm Families and the Ecology of Intensive, Sustainable Agriculture. Stanford University Press, Stanford, California.

Norr, Lynette

1995 Interpreting Dietary Maize from Bone Stable Isotopes in the American Tropics: The State of the Art. In Archaeology in the American Tropics: Current Analytical Methods and Applications, edited by Peter W. Stahl, pp. 198-223. Cambridge University Press, Cambridge.

Pillsbury, Joanne (editor)

2001 Moche Art and Archaeology in Ancient Peru. Studies in the History of Art 63, Center for the Advanced Study in the Visual Arts, Symposium Papers XL. National Gallery of Art, Washington, D.C.

Pozorski, Sheila

1979 Prehistoric Diet and Subsistence of the Moche Valley, Peru. World Archaeology 11:163-184.

1983 Changing Subsistence Priorities and Early Settlement Patterns on the North Coast of Peru. Journal of Ethnobiology 3:15-38.

Pozorski, Sheila, and Thomas Pozorski

1979 An Early Subsistence Exchange System in the Moche Valley, Peru. Journal of Field Archaeology 6:413-432

Pozorski, Thomas

1982 Early Social Stratification and Subsistence Systems: The Caballo Muerto Complex. In Chan Chan: Andean Desert City, edited by Michael E. Moseley and Kent C. Day, pp. 225-253. University of New Mexico Press, Albuquerque.

Price, T. Douglas, Margaret J. Schoeninger, and George J. Armellagos

1985 Chemistry and Past Human Behavior: An Overview. Journal of Human Evolution 14:419-447.

Quilter, Jeffrey, and Luis Jaime Castillo Butters (editors)

2010 New Perspectives on Moche Political Organization. Dumbarton Oaks Pre-Columbian Symposia and Colloquia, Washington, D.C.

Quilter, Jeffrey, and Terry Stocker

1983 Subsistence Economies and the Origins of Andean Complex Societies. American Anthropologist 85:545-562.

Ramirez, Susan E.

1996 The World Upside Down: Cross-Cultural Contacts 
and Conflict in Sixteenth-Century Peru. Stanford University Press, Stanford, California.

Reimer, Paula J., Mike G. L. Baillie, Edouard Bard, Alex Bayliss, J. Warren Beck, Chandra Bertrand, Paul G. Blackwell, Caitlin E. Buck, George Burr, Kirsten B. Cutler, Paul E. Damon, R. Lawrence Edwards, Richard G. Fairbanks, Michael Friedrich, Thomas P. Guilderson, Konrad A. Hughen, Bernd Kromer, F. Gerry McCormac, Sturt Manning, Christopher Bronk-Ramsey, Ron W. Reimer, Sabine Remmele, John R. Southon, Minze Stuiver, Sahra Talamo, Frederick W. Taylor, Johannes van der Plicht, and Constance E. Weyhenmeyer

2009 IntCal09 and Marine09 Radiocarbon Age Calibration Curves, 0-50,000 Years cal B.P.Radiocarbon 51:1111-1150.

Sandness, Kari L.

1992 Temporal and Spatial Dietary Variability in the Prehistoric Lower and Middle Osmore Drainage: The Carbon and Nitrogen Stable Isotope Evidence. Unpublished M.A. thesis, University of Nebraska, Lincoln.

Schurr, Mark R., and Brian G. Redmond

1991 Stable Isotope Analysis of Incipient Maize Horticulturists from the Gard Island 2 Site. Midcontinental Journal of Archaeology 16:69-84.

Sealy, Judith C.

1986 Stable Carbon Isotopes and Prehistoric Diets in the Southwestern Cape Province, South Africa. BAR International Series 293. British Archaeological Reports, Oxford.

Sealy, Judith C., and Nikolaas J. van der Merwe

1998 Social, Spatial and Chronological Patterning in Marine Food Use as Determined by $\delta^{13} \mathrm{C}$ Measurements of Holocene Human Skeletons from the South-Western Cape, South Africa. World Archaeology 20:87-102.

Sealy, Judith C., Nikolaas J. van der Merwe, Julia A. Lee-Thorp, and J. L. Lanham

1987 Nitrogen Isotopic Ecology in Southern Africa. Implications for Environmental and Dietary Tracing. Geochimica et Cosmochimica Acta 51:10:2707-2717.

Slovak, Nicole M., and Adina Paytan

2011 Fisherfolk and Farmers: Carbon and Nitrogen Isotope Evidence From Middle Horizon Ancon, Peru. International Journal of Osteoarchaeology 21:253-267.

Stanish, Charles

1994 The Hydraulic Hypothesis Revisited: Lake Titicaca Basin Raised Fields in Theoretical Perspective. Latin American Antiquity 5:312-332.

Stuiver, Minze, and Paula J. Reimer

2010 Radiocarbon Calibration Program: Calib Rev. 6.0. Electronic document, http://calib.qub.ac.uk/calib/ calib.html, accessed October, 2010.

Tello, Richardo, José Armas, and Claude Chapdelaine

2003 Prácticas funerarias moche en el complejo arqueológico Huaca del Sol y de la Luna. In Moche: hacia el final del mileni.: Actas del Segundo Coloquio sobre la Cultura Moche, edited by Santiago Uceda C. and Elías Mujica,pp. 151-187. Universidad Nacional de Trujillo and Fondo Editorial de la Pontificia Universidad Católica del Perú, Lima.

Tieszen, Larry L., and Tim Fagre

1993 Effect of Diet Quality and Composition on the Isotopic Composition of Respiratory CO2, Bone Collagen, Bioapatite, and Soft Tissues. In Prehistoric Human Bone: Archaeology at the Molecular Level, edited by Joseph B. Lambert and Gisella Grupe, pp. 121-156. Springer-Verlag, Berlin.

Tomczak, Paula D.

2003 Prehistoric Diet and Socioeconomic Relationships
Within the Osmore Valley of Southern Peru. Journal of Anthropological Archaeology 22:262-278.

Topic, Theresa

1977 Excavations at Moche. Unpublished Ph.D. dissertation, Department of Anthropology, Harvard University, Cambridge.

1982 The Early Intermediate Period and Its Legacy. In Chan Chan: Andean Desert City, edited by Michael E. Moseley and Kent C. Day, pp. 255-284. University of New Mexico Press, Albuquerque.

Tucker, Bryan D.

2002 Culinary Confusion: Using Osteological and Stable Isotopic Evidence to Reconstruct Paleodiet for the Ocmulgee/Blackshear Cordmarked People of the south Central Georgia. Unpublished Master's thesis, Department of Geography and Anthropology, Georgia State University, Atlanta.

Turner, Christy G.

1979 Dental Anthropological Indications of Agriculture among the Jomon People of Central Japan. American Journal of Physical Anthropology 51:619-636.

1993 Human Dentition from the Akari Site, Madang, Papua New Guinea, with Observations on the Oldest Known Interproximal Tooth Groove in Australmelanesia. Bulletin of Indo-Pacific Prehistory 13:15-19.

Turner, Christy G., and James D. Cadien

1969 Dental Chipping in Aleuts, Eskimos and Indians. American Journal of Physical Anthropology 31:303-310.

Tykot, Robert $\mathrm{H}$.

2006 Isotope Analyses and the Histories of Maize. In Histories of Maize: Multidisciplinary Approaches to the Prehistory, Linguistics, Biogeography, Domestication, and Evolution of Maize, edited by John E. Staller, Robert H. Tykot, and Bruce F. Benz, pp. 131-142. Academic Press, New York.

Tykot, Robert H., Richard Burger, and Nikolaas J. van der Merwe

2008 The Importance of Maize in Initial Period and Early Horizon Peru. In Histories of Maize: Multidisciplinary Approaches to the Prehistory, Linguistics, Biogeography, Domestication, and Evolution of Maize, edited by John E. Staller, Robert H. Tykot and Bruce F. Benz, pp. 187-197. Academic Press, New York.

Tykot, Robert H., Fernanda Falabella, María Teresa Planella, Eugenio Aspillaga, Lorena Sanhueza, and Cristian Becker

2009 Stable Isotopes and Archaeology in Central Chile: Methodological Insights and Interpretive Problems for Dietary Reconstruction. International Journal of Osteoarchaeology 19:156-170.

Tykot, Robert H., and John E. Staller

2002 The Importance of Early Maize Agriculture in Coastal Ecuador: New Data from La Emerenciana. Current Anthropology 43:666-677.

Ubelaker, Douglas. H., M. Anne Katzenberg, and L. G. Doyon 1995 Status and Diet in Precontact Highland Ecuador. American Journal of Physical Anthropology 97:403-411.

Uceda C., Santiago

2001 Investigations at Huaca de la Luna, Moche Valley: An example of Moche religious architecture. In Moche Art and Archaeology in Ancient Peru, edited by Joanne Pillsbury, pp. 47-67. Studies in the History of Art 63. Center for Advanced Studies in the Visual Arts, Symposium Papers XL. National Gallery of Art, Washington, D.C.

Uceda, Santiago, and José Armas

1997 Los talleres alfareros en el centro urbano Moche. In Investigaciones en la Huaca de la Luna 1995, edited by Santiago Uceda, Elías Mujica, and Ricardo Morales, pp. 
93-104. Facultad de Ciencias Sociales, Universidad Nacional de la Libertad-Trujillo, Peru.

1998 An Urban Pottery Workshop at the Site of Moche. In Andean Ceramics: Technology, Organization, and Approaches, edited by Izumi Shimada, pp. 91-110. MASCA Research Papers in Science and Archaeology, Supplement to Volume 15. University of Pennsylvania Museum of Anthropology and Archaeology, Philadelphia.

Uceda C, Santiago, Ricardo G. Morales, José A. Canciani, and María V. Montoya

1994 Investigaciones sobre la arquitectura y relieves polícromos en la Huaca de la Luna, Valle de Moche. In Moche: propuestas y perspectivas, edited by Santiago Uceda C. and Elías Mujica, pp. 251-306. Universidad Nacional de la Libertad, Trujillo.

van der Merwe, Nikolaas J., Julia A. Lee-Thorp, and J. Scott Raymond

1993 Light Stable Isotopes and the Subsistence Base of Formative Cultures at Valdivia, Ecuador. In Prehistoric Human Bone: Archaeology at the Molecular Level, edited by Joseph B. Lambert, and Gisela Grupe pp. 63-97. Springer-Verlag, Berlin.

van Der Merwe, Nikolaas J., and John C. Vogel

$1978{ }^{13} \mathrm{C}$ Content of Human Collagen as a Measure of Prehistoric Diet in Woodland North America. Nature 276:815-816.

Verano, John W.

2000 Paleontological Analysis of Sacrificial Victims at the Pyramid of the Moon, Moche River Valley, Northern Peru. Chungará (Arica) 32:61-70.

2001 The Physical Evidence of Human Sacrifice in Ancient Peru. In Ritual Sacrifice in Ancient Peru, edited by Elizabeth P. Benson and Anita G. Cook, pp. 165-184. University of Texas Press, Austin.

Vogel, John C., and Nikolaas J. van der Merwe

1977 Isotopic Evidence for Early Maize Cultivation in New York State. American Antiquity 42:238-242.

Wachter, Eric A., and John M. Hayes

1985 Exchange of Oxygen Isotopes in Carbon Dioxidephosphoric [Correction of Phosphoric] Acid Systems. Chemical Geology: Isotope Geoscience Section 52, 365-374.

Walker, Phillip L., and Michael J. DeNiro

1986 Stable Nitrogen and Carbon Isotope Ratios in Bone Collagen as Indices of Prehistoric Dietary Dependence on Marine and Terrestrial Resources in Southern California. American Journal of Physical Anthropology 71:51-61.

White, Tim D., and Pieter A. Folkens

2005 The Human Bone Manual. Elsevier, Amsterdam.

Wilson, David J.

1981 Of Maize and Men: A Critique of the Maritime Hypothesis of State Origins on the Coast of Peru. American Anthropologist 83:93-120.
1988 Prehispanic Settlement Patterns in the Lower Santa Valley Peru: A Regional Perspective on the Origins and Development of Complex North Coast Society. Smithsonian Institution Press, Washington, D.C.

Wittfogel, Karl A.

1956 The Hydraulic Civilizations. In Man's Role in Changing the Face of the Earth, edited by William L. Thomas, pp. 152-164. Wenner-Gren Foundation, Chicago.

1971 Developmental Aspects of Hydraulic Societies. In Prehistoric Agriculture, edited by Stuart Struever, pp. 557-571. The Natural History Press, Garden city, New York. Originally published 1955, in Irrigation Civilizations: A Comparative Study, edited by Julian Haynes Steward, Robert M. Adams, Donald Collier, Angel Palerm, Karl A. Wittfogel, and Ralph L. Beals. Pan American Union Press, Washington, D.C.

Wright, Lori E., and Henry P. Schwarcz

1996 Infrared and Isotopic Evidence for Diagenesis of Bone Apatite at Dos Pilas, Guatemala: Palaeodietary implications. Journal of Archaeological Science 23:933-944.

1998 Stable Carbon and Oxygen Isotopes in Human Tooth Enamel: Identifying Breastfeeding and Weaning in Prehistory. American Journal of Physical Anthropology 106:1-18.

Yesner, David, María José Figuerero Torres, Ricardo A. Guichon, and Luis A. Borrero

2003 Stable Isotope Patterns in Tierra del Fuego. Journal of Anthropological Archaeology 22:279-291.

\section{Notes}

1. In this article we use the name "Southern Moche state" for the regional political economy that emerged at Huacas de Moche in the Moche Valley during the first few centuries A.D. We use this name as a term of convenience. We wish to avoid arguments over "whether or not Moche was a state," and to focus instead on the nature of Moche political relationships, especially the nexus of the political economy and the domestic economy. In short, how power was negotiated between heterogenous groups of rulers and farming, fishing and crafting households.

2. Sequential page numbers were assigned to this unnumbered report; the introduction is page 1 .

Submitted December 27, 2010; Accepted November 2, 2011; Revised January 7, 2012. 